Discussion Papers

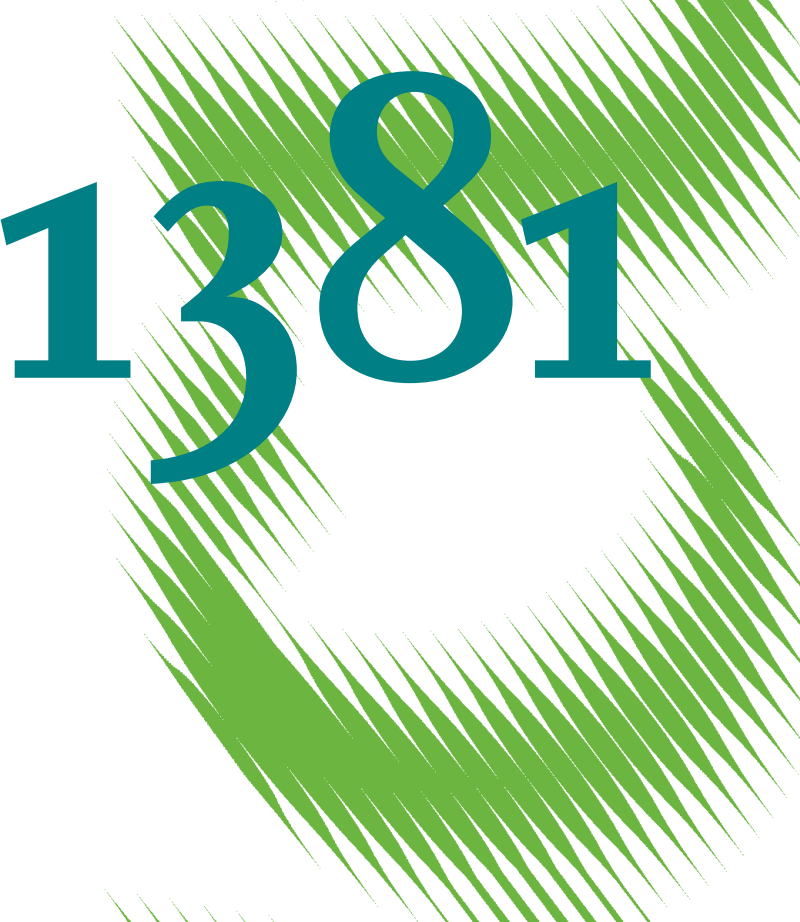

WATER-Model

An Optimal Allocation of Water Resources in

Turkey, Syria and Iraq 
Opinions expressed in this paper are those of the author(s) and do not necessarily reflect views of the institute.

IMPRESSUM

(C) DIW Berlin, 2014

DIW Berlin

German Institute for Economic Research

Mohrenstr. 58

10117 Berlin

Tel. $+49(30) 89789-0$

Fax +49 (30) $89789-200$

http://www.diw.de

ISSN print edition $1433-0210$

ISSN electronic edition 1619-4535

Papers can be downloaded free of charge from the DIW Berlin website:

http://www.diw.de/discussionpapers

Discussion Papers of DIW Berlin are indexed in RePEc and SSRN:

http://ideas.repec.org/s/diw/diwwpp.html

http://www.ssrn.com/link/DIW-Berlin-German-Inst-Econ-Res.html 


\title{
WATER-Model An Optimal Allocation of Water Resources in Turkey, Syria and Iraq
}

\author{
Pao-Yu Oei* Markus Siehlow ${ }^{\dagger}$
}

May 21, 2014

\begin{abstract}
Political instability of several countries in the Middle East is overshadowing one of the biggest challenges of the upcoming century: Water - a natural resource that is easily taken for granted, but whose scarcity might lead to serious conflicts. This paper investigates an optimal Water Allocation of the Tigris and Euphrates Rivershed by introducing the WATER-Model. A series of scenarios are analyzed to examine the effects of different levels of cooperation for an optimal water allocation. Special emphasize is put on the effects of filling new Turkish reservoirs which can cause additional welfare losses if these actions are not done on a basin-wide coordinated basis.

Modeling results show that Turkey is most efficient in its water usage. However, using the water for irrigation purposes in Turkey, instead of the Iraqi or Syrian domestic and industrial sector, decreases the overall welfare. Especially the Euphrates basin might thus encounter losses of up to $33 \%$ due to such strategic behaviour. The predicted water demand growth in the region is going to increase this water scarcity further. Minimum flow treaties between riparian countries, however, can help to increase the overall welfare and should therefore be fostered.
\end{abstract}

Keywords: Integrated Water Resources Management, Euphrates Tigris rivershed, non linear modeling, transboundary water resources allocation

JEL Codes: C61, Q25, O53, D74

\footnotetext{
${ }^{*}$ Corresponding Author. DIW Berlin, Department Energy, Transportation and Environment (EVU), and TU Berlin, Workgroup for Economic and Infrastructure Policy (WIP), Germany, pyo@wip.tu-berlin.de. ${ }^{\dagger}$ DIW Berlin, EVU and TU Berlin, WIP, Berlin, Germany.
} 


\section{Introduction}

"The Garden of Eden" mentioned in the first book of Mose describes the birthplace of humanity and is translated by the word Paradise in the Greek translation of the Jewish Tanach. The Biblical scripture does mention four rivers springing from the Garden of Eden: Pishon, Gihon, Tigris and Euphrates. The first two rivers can not be clearly identified, therefore leaving room for interpretation. Some scholars, however, assume Gihon to be the Iranian Karkheh river, which is a tribuatry of the Tigris. The Tigris and Euphrates have been mentioned several times in the Bible and describe the region of Mesopotamia (Greek for between the rivers). Therefore, many theologists and scientists believe, that the real location of "The Garden of Eden" must lie in today's Iraq or Turkey, where also Noah's Ark came to rest on Mount Ararat. (HiLL, 2000 and CGM, 2012)

This paper is dealing with the problematic of a fair distribution of water inside this Tigris-Euphrates (TE) Watershed. Many disputes in the Middle East have been triggered of by conflicts over petroleum resources but in the coming centuries a new much more essential natural resource conflict is arising: The conflict about water. The TE-Watershed is located inside the former Ottoman Empire and is now divided by the territories of Turkey, Syria and Iraq which are in the up-, mid- and downstream position respectively. (KibAROGLU, 2008)

Water management in the three riparian states was harmonized untill the first half of the $20^{\text {th }}$ century. (Allan, 2002) Even ineffective and inefficient managements did not have substantial negative impacts on quantity and quality of the rivers. (KIBAROGLU AND ÜNVER, 2000) At the beginning of the 1960s, the riparian states announced ambitious plans to use water from the rivers for energy and irrigation purposes. These plans affected riparian relations significantly. The biggest fear was and still is, that upstream administrative divisions like Turkey may divert water in an unsustainable way from potential downstream users such as Syria and Iraq. In case of an uprising and breaking apart of regions (e.g. Kurdistan) this might increase the number and complexity of water divisions and lead to a further negligence of downstream users. (Geopolicity, 2010 and Jobson, 2003)

The legal regime currently in place is the "Treaty of Friendship and Neighborly Relation" between Iraq and Turkey which was signed in 1946. It states that Turkey should consult with Iraq upon the building of any upstream projects and make adjustments such that the water needs for both nations are satisfied. (ELHANCE, 1999) This treaty is theoretically still in force, but falls short for providing a legal regime to govern water sharing in the basin, because of excluding Syria and not specifying how the terms of "consultation" will be defined and adjudicated. (ElHance, 1999 and Dinar, 2012)

In 1975 for example, Syria diverted a large portion of its runoff to the reservoir AthThawrah which created severe water shortages for million Iraqi farmers. Due to this situation the political tension increased and both countries dispatched armed soldiers to their borders. At the end, Saudi-Arabia and the Soviet Union intervened in the conflict as mediators and prevented a war between both riparian states. (ElHANCE, 1999)

Turkey asserts, that there is sufficient water in the basin and accuses Syria and Iraq for mismanaging the water resources in their territories. Turkey argues that it has therefore 
the full right to utilize the watercourse in its territory until it reaches Syria. (ZAwAHRI, 2006 and Williams, 2011) Due to its superior geographical position, its large contribution to total runoff and its economic as well as military power, Turkey is in a position to make hegemonic claims vis-à-vis its downstream neighbors. (DinAR, 2012) Turkey initiated the Southeastern Anatolia Development Project (GAP) to develop land and water resources covering the construction of 22 dams and 19 hydro-power plants to irrigate additional 1.7 million ha and produce 27 billion kWh of electricity per year through a total capacity of $7460 \mathrm{MW}$. When the project is finished it will employ additional 3.8 million people and increase the per capita income by 209 percent in the Turkish upstream area of the Tigris and Euphrates. The total GAP area is bigger than the Benelux, Denmark, and Ireland alltogether. The overall costs of this project were estimated to be 23 billion USD. By the end of 200714.3 billion USD had already been spent, while having completed the construction of 15 dams. These dams offer a potential capacity sufficient for irrigating 1 million ha, but only 15 percent has been realized so far. (GAP, 2006 and GAP, 2011) OzdoGan ET AL. (2006) observed a three-fold of summer irrigated cropland acreage in the Turkish Harran Plain between 1993 and 2002. This shows that the Turkish government has great hopes and visions for the TE-Watershed, but raises the question of how this might affect water supply in the mid- and downstream countries.

The GAP project serves an economic and a political purpose for Turkey: On the one hand, it is securing the country's energy and food supply. On the other hand it is also integrating the primarily Kurdish area into economic development programs, which might weaken ethnically and historically motivated opposition in these areas through socioeconomic development and the provision of employment opportunities. (LEB, 2010)

Integrated water management programs like the GAP have the potential of increasing the water usage in some areas, but often do penalize other riparian regions, thus causing political tensions. Scientists and politicians claim, that the construction of Turkish dams has already caused a significant change in the flow regime of the Euphrates and to a lesser extent also of the Tigris. (Ruf, 2006) This change has come in terms of quality (e.g. higher water salinity and pollution) as well as quantity. (Elhance, 1999, KIBARoglu AND ÜNVER, 2000 and DAOUdy, 2009) RAHI AND HALiHAN (2010) state, that the water salinity of the Euphrates River, when entering Iraq from Syria, has more than doubled compared to figures from 1973. In addition to that, Iraq is trying to compensate these decreasing inflows by diverting flows from the $\mathrm{Al}$ Tharthar Lake and irrigation return flows into the Euphrates, thus leading to a further deterioration of water quality. Salination values thus have increased from 1,080 ppm in 1979 to more than 4,500 ppm in 2001 in the downstream regions of the Euphrates at Al Nassiriah. This major threat to the environment and the agriculture will probably worsen with a full implementation of the GAP project. Some studies also predict that global climate change might lead to a longer and hoter dry period, increasing the problem of water scarcity in the region (Evans, 2009, Brown and Crawford, 2009 as well as Tolba And SaAB, 2009).

Furthermore, Syria and Iraq claim, that their own planned water projects will need additional release from Turkey. They particularly refer to the UN Convention on the Law of Non-Navigable Uses of International Watercourses as well as further general international obligations. Their claims for Turkey are to notify, consult and negotiate all downstream 
or affected riparian states with respect to all maters of water usage (KURDISH HUMAN Rights ProjeCt, 2002). Both downstream countries seek a comprehensive regime for apportioning the water in the basin. They base their claims on the international clause of appreciable harm which requires states to refrain from causing harm to other states when using common water resources. Iraq also utilizes the clause of acquired rights, given its historical use of water prior to use by Syria and Iraq. (DINAR, 2012). Turkey's government argues that sharing the water is not an adequate response to prevent water scarcity in long term and would not serve the goals of sustainable use and management (KRAMER AND Kibaroglu, 2011). The aim of the two downstream countries is to invert the situation of power asymmetry in the basin by their political and diplomatic actions. For example Syria blocked the international investments in GAP which diminish Turkey's ability to obtain external funding. (ZAWAHrI, 2006) Due to this, the implementation of Turkey's water utilization projects was delayed, but its economic boom allowed Turkey to turn inward to meet parts of its financing needs. (KibarogLU ET AL., 2005, Kibaroglu AND Scheumann, 2011, Tigrek and Kibaroglu, 2011)

The key to improved hydro-political relations between Turkey and Syria as well as Turkey and Iraq could be Turkey's bid for EU membership as well as Turkey's growth as a global power. These political ambition forces Turkey to act in a more cooperative manner. (CAGAPtAY, 2012 and DinAR, 2012) For example, since the beginning of the second Gulf War, Turkey and Syria have became close allies. Two framework cooperation agreements were signed in 2003 and 2004 between both countries which contain for instance arrangements about water conservation in agricultural practice as well as efforts to combat waterborne disease. (Kibaroglu and Scheumann, 2011) The memorandum of understanding was signed in 2009 between Syria and Turkey as well as between Turkey and Iraq which covers issues such as information exchange, water utilization, hydropower, drought and water quality. (KIBARoglu And Scheumann, 2011 ) The recent cooperative initiatives confirm Turkey's good will towards Syria and Iraq and indicate a changing dynamic in the basin.

An example for linking the water issue with unrelated issues is the protocol on "Matters Pertaining to Cooperation" which was signed in 1987 by Turkey and Syria. It guarantees a minimum flow in the Euphrates from Turkey to Syria in exchange for acknowledgments on border issues which ranged from smuggling to infiltration into Turkey by separatist groups. (ElHANCE, 1999) Syria also signed an agreement with Iraq in 1990 by which it releases 58 percent of the Euphrates flow, reaching Syria at its northern border, to Iraq. (DINAR, 2012)

Despite the bilateral agreements, there is a lack of tri-lateral comprehensive agreements and there is currently no common coordination about the future development of the two rivers. (ZAWAHRI, 2006) AKANDA ET AL. (2007) state, that the implementation of all water projects in the basin would require divertable water volumes that exceed the average annual runoff of both rivers by about 50 percent.

The recent political instability in the two downstream countries as well as Turkey's military, economic and geographic status in the basin strengthen Turkey's hegemonic power and makes a fair cooperative water distribution management regime between the riparian states not realistic. (DinAR, 2012) 
Some people try to compare the situation of the Nile with the Tigris and Euphrates basin, not paying attention to the big differences regarding the division of (military) power inside the basin. The economic and military situations of Turkey, Syria and Iraq are very different as it can be seen in table 1. Recent economic and political happenings in the regions have led to an increasing gap between Turkey on the one hand and Syria and Iraq on the other hand. Turkey, currently also having the biggest political support in the western world, therefore clearly is the dominant player in the region, similar to Egypt in the Nile basin. On the contrary to Egypt, Turkey though is situated at the spring of both rivers thus using its military superiority only to foster its geographical advantage. Iraq and Syria on the other hand, situated on the downstream parts, lack the political and military power to demand minimum water flows from Turkey. Some critics, however, predict the political power of Iraq to rise in the coming decades, once the country stabilizes and thus advice Turkey to agree on longterm water contracts now, while still being the dominant player. (MacQuarrie, 2004)

Table 1: Economic indicators for the countries of the TE-Watershed

\begin{tabular}{l|ccccc}
\hline Country & $\begin{array}{c}\text { GDP } \\
\text { per } \\
\text { capita }\end{array}$ & $\begin{array}{c}\text { Oil rents } \\
\text { from } \\
\text { GDP }\end{array}$ & $\begin{array}{c}\text { Secondary } \\
\text { School } \\
\text { Enrollment }\end{array}$ & $\begin{array}{c}\text { Agricultural } \\
\text { land } \\
\text { ratio }\end{array}$ & $\begin{array}{c}\text { World Rank } \\
\text { in military } \\
\text { strength }\end{array}$ \\
\hline Iraq & $6,455 \$$ & $78 \%$ & $53 \%$ & $19 \%$ & $58^{\text {th }}$ \\
Syria & $3,289 \$$ & $16 \%$ & $72 \%$ & $75 \%$ & $39^{\text {th }}$ \\
Turkey & $10,666 \$$ & $0.2 \%$ & $87 \%$ & $50 \%$ & $11^{\text {th }}$ \\
\hline
\end{tabular}

Source: World Bank (2013) and Global Fire Power (2011).

A sustainable joint usage of the Euphrates and Tigris, however, increases the overall welfare and could thus foster political stability in that region. Therefore, this paper investigates an optimal Water Allocation of the Tigris and Euphrates Rivershed by introducing the WATER-Model. The model analyses welfare losses due to strategic behaviors of countries. Additional scenario runs furthermore calculate the effects of the completion of the GAP project as well as the predicted increase of the water demand till 2030.

This introduction is followed by a literature overview concentrating on existing river basin models, especially in the Tigris-Euphrates Rivershed. The third chapter is dedicated to an extensive description of the WATER-Model and its mathematical formulation. All used data sets and assumptions are explained and listed in the fourth chapter. Chapter five describes the character of the different scenarios. The results of all model runs are interpreted in the sixth chapter, before finishing with an overall conclusion in chapter seven. 


\section{Literature Overview}

There is a wide range of publications that deal with international relations, hydropolitics or international water law issues in the Euphrates and Tigris river basin. KIBAROGLU AND SCHEUmann (2013) analyze the evolution of transboundary water relations over four periods, beginning with the nation building in the region until the phase in which the reorientation of water policies from hostile to cooperative became significant. ELVER (2002) explores the transnational arrangements among Turkey, Syria and Iraq for the allocation of river resources. The author explains the potential for conflicts as well as the role that international law can play in resolving such conflicts. WARNER (2008) evaluates the Turkish hegemony on its hydraulic control and security strategy. He argues, that Turkey's regional hegemony is constrained and contested from different sides, e.g. due to its need to access capital in the international market to realize its ambitious infrastructure plans. In a latter publication WARNER (2012) describes the factors, that opened up the space for the GAP project.

There is a multitude of publications concentrating on the modeling of river basins. In this field, optimization models sometimes combined with techniques from cooperative game theory are often used to answer the respective research questions. A review about these kind of literature is given by Dinar ET AL. (2007) while Brouwer AND Hofkes (2008) as well as HAROU ET AL. (2009) write about hydro-economic modeling in general. Wu AND Whittington (2006) focus on incentive-compatible cooperation in the Nile River Basin. To calculate the benefits from water use for cooperative and non-cooperative strategies the authors use a water allocation optimization model. They give evidence that each riparian state will benefit in a scheme in which all member states cooperate within the framework of a grand coalition.

GOHAR AND WARD (2010) calculate the potential for optimizing the Egyptian irrigation use along the Nile River. The model maximizes the total agricultural income subject to numerous hydrologic, environmental, and institutional constraints. The results state that an expanded intra-regional water trading among Egyptians could raise the economic performance.

MCKinney, KARIMOV AND CAI (1997) developed a water allocation model in which they use a multiple-objective approach for the tributaries of the Aral sea, the Amudarya River and the Kashkadarya. Results point out, that putting more weight on salt management uses less water in the upstream region and thus increases the flow to the Aral Sea. The authors recommend the model as a tool for decision makers to perform tradeoff analyses. SieHLOW ET AL. (2013) use a sequential welfare maximization approach to compute an inter-temporal optimal water allocation in the Orange-Senqu river basin. They examine 108 different cooperation options. By using techniques of cooperative game theory the authors identify bargaining power and the range of side-payments in the basin essential to form a grand coalition, between all the entities in the basin, which has the potential for increasing the overall welfare, significantly.

DAVIS ET AL. (2004) developed a hydrologic model for the TE-basin focusing on socioeconomic and environmental aspects. Their emphasize is to build a tool for future studies 
of marsh reflooding and restoration, including health care for the marsh population. The model itself, however, mainly concentrates on Iraq and is lacking sufficient data inputs in the upstream region.

Kucukmehmetoglu and Guldmann (2004) program the "Euphrates and Tigris River Basin Model" (ETRBM) which is a linear programming model for maximizing net economic benefits in the TE-Watershed. Later versions of the ETRBM transfer it to InterTemporal Euphrates and Tigris River Basin Model (ITETRBM) focusing on the potential political and economic impacts of reservoirs from an inter-temporal perspective (KUCUKmenmetoglu, 2009 as well as Kucukmehmetoglu and Guldmann, 2010). They conclude that basin-wide coalitions can work as substitute for the construction of further costly reservoirs and should therefore be fostered. In KuCUKMEHMETOGLU ET AL. (2010) the authors combine game theory and a fuzzy modeling approach to deal also with linguistic data in the basin. Another approach with the integration of both game theory and Pareto frontier concepts is done in Kucukmenmetoglu (2012). The approach searches for an acceptable solution set over the Pareto frontier surface via cooperative game theory based constraints.

GüNER (1999) uses noncooperative game theory to model Turkish-Syrian interactions regarding terrorism and water. Iraq benefits from Turkish-Syrian concessions, but has no choice due to its downstream position. A unique equilibrium stipulates the condition for a cooperation between both upstream countries. Therefore, Turkish-Iraqi and Syrian-Iraqi alliances are being formed, to balance threats in the basin.

Tilmant and Kelman (2007) present a methodology based on stochastic dual dynamic programming for analyzing trade-offs under hydrological uncertainty. This methodology is applied to the GAP project. Simulation results show that the complete development of the irrigation projects would reduce the total energy output significantly and will increase the risk of not meeting minimal outflows to Syria. In a subsequent publication TiLmanT ET AL. (2008) present a stochastic programming approach for assessing the distribution of marginal water values in a cascade of hydroelectric-irrigation reservoirs in the Euphrates in Turkey and Syria.

ÖZTAN AND AXELRod (2011) use a simulation model for groundwater flows. They show how enhanced cooperation between Turkey and Syria could impact the Ceylanpinar aquifer which flows beneath both countries.

In the following section we present a non-linear welfare maximizing model to optimize the "Water Allocation of the Tigris and Euphrates Rivershed" - also known as WATERModel. In contrast to the models presented above this model is used to analyse not only present but also future water demand. The different model settings enable the analysis of co-operative as well as non-cooperative behaviour of the different countries. Its scope covers the entire Euphrates Tigris basin. Moreover it is scalable, allowing to focus on specific regions for additonal scenario insights, if needed. 


\section{Model Formulation}

\subsection{Network Illustration}

The WATER-model consists of two periods, both lasting for six months. January till June can be identified as rainy period, while only litte rainfall can be seen in the dry period from July till December. The storage option in the included dams and reservoirs enables the model to simulate water storage for upcoming dryer periods and thus still satisfy all minimal demands. Other water in- and outflows depend on tributary inflows, evaporation losses as well as backflows from upstream demand centres. Several off-stream usages have been modeled differentiating between agricultural, domestic and industrial sector. See figure 1 for the visualization of the decision tree of the WATER-Model.

Figure 1: Decision tree of the WATER-MODEL

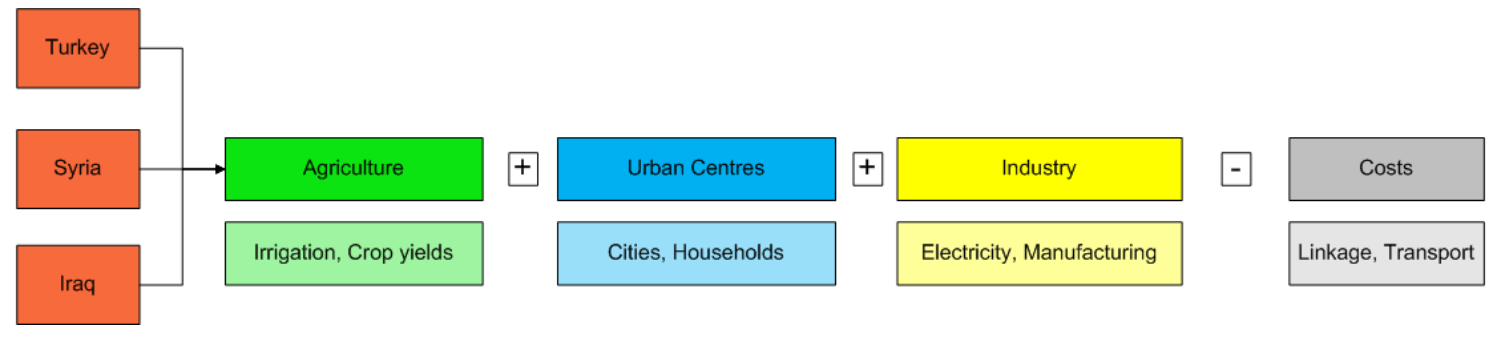

Source: Own illustration;

The figure 2 shows the Tigris-Euphrates Rivershed with the modeled network of the WATER-Model and its nodes. 16 nodes are transport nodes (T1-T16 in blue) at which an inflow through tributaries as well as storage and evaporation is possible. The demand nodes resemble demand centres for agricultural, domestic and industrial usage, depending on their individual infrastructure and potential. All nine divisions of Turkey that are part of the GAP region are included as nodes, resembling nine domestic, seven agricultural and five industrial demand centres (dT1-dT9 in red). Syria has four regions adjacing the TEWatershed which are resembled by seven nodes in which seven domestic, six agricultural and two industrial demand centres are active (dS1-dS7 in green). Iraq's 18 divisions are shown as 18 nodes resembling 18 domestic, eight agricultural and six industrial demand centres (dI1-dI18 in yellow). The WATER-Model is fully scalable, enabling an up- or downscaling of the number of nodes, if a closer or wider perspective is needed. 
Figure 2: Map of the TE-basin and all nodes of the WATER-ModeL

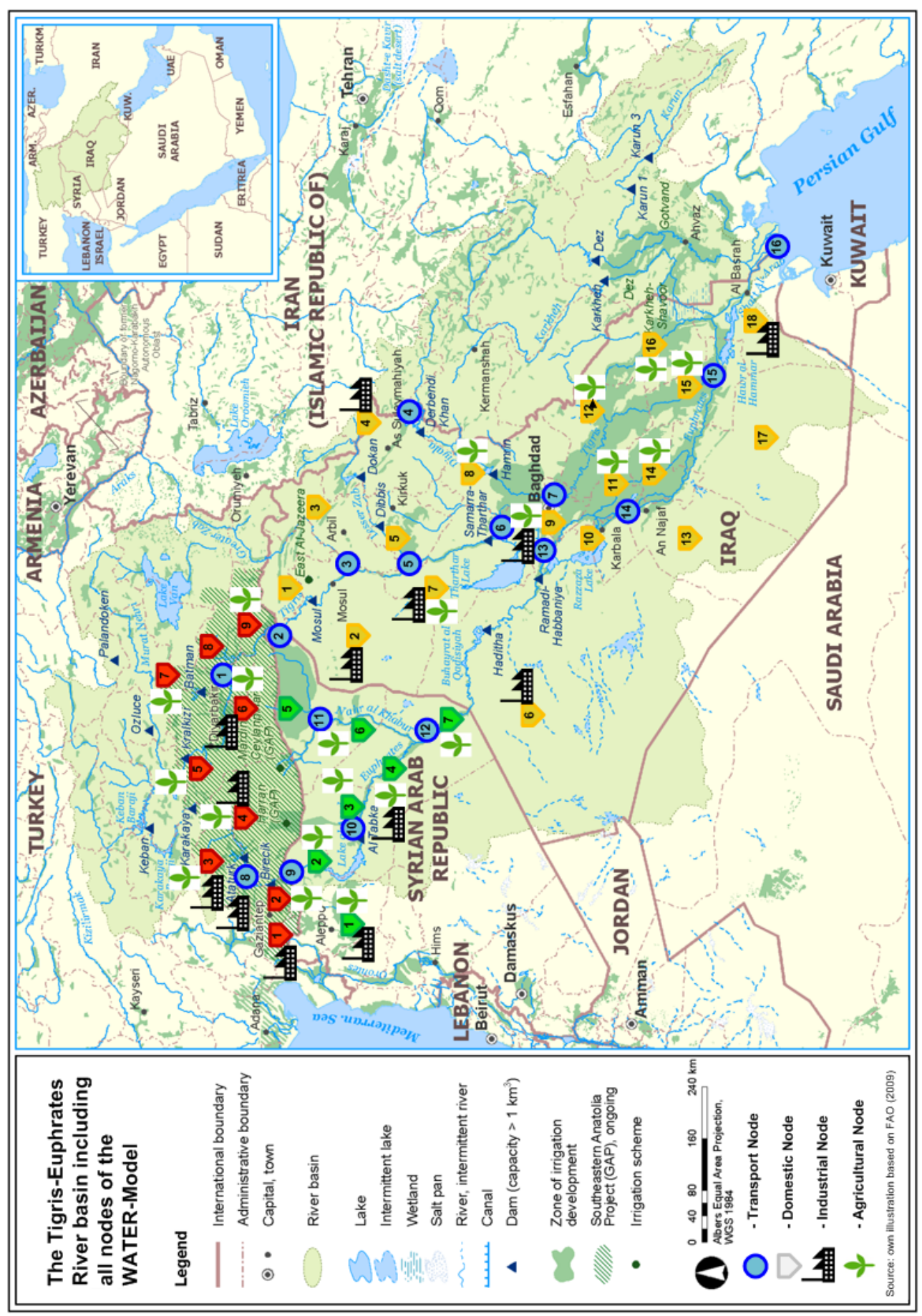

Source: Own illustration based on FAO (2009b) 


\subsection{Mathematical Formulation}

We use a Quadratically Constrained Problem (QCP) where an omniscient planner maximizes the overall welfare for all three countries. Welfare is defined as the sum of producer and consumer surplus assuming a linear demand function. It can be calculated as the area below the demand curve subtracted by all variable costs such as operation and maintenance or pumping costs. The price only depends on the sectoral consumption $d$ at that node as no global water trading market exists. Transferring this general welfare definition into this river basin modeling approach we define a specific demand $d_{\text {agir }}$ for every node. It depends on the time period $a$ (rainy or dry), the consumption group $g$ (households, industry, or agriculture), the specific node location $i$ (or its alias $j$ ) and the region $r$ (Turkey, Syria, Iraq) (see Appendix for further notations of the model). The area below the demand curve is calculated using the following equation including the slope $m_{a g i}$ and the prohibitive price $n_{a g i}$ :

$$
d \_ \text {area } a_{a, g, i, r}=\left[0.5 \cdot m_{a, g, i} \cdot\left(d_{a, g, i, r}\right)^{2}+n_{a, g, i} \cdot d_{a, g, i, r}\right] \quad \forall \quad a, g, i, r
$$

This area has to be subtracted by all costs to calculate the welfare. $c_{a, g, i, r}$ are the variable costs for delivering the water to its consumption nodes including pumping as well as maintenance costs. The model calculates the overall welfare for all different sectors of all riparian countries over one year only; thus investment costs are not taken into consideration. The costs for storing one $m^{3}$ of water are $c \_s t o r_{i}$ being multiplied by the endogenous storage variable stor_in $i n_{a, i, r}$.

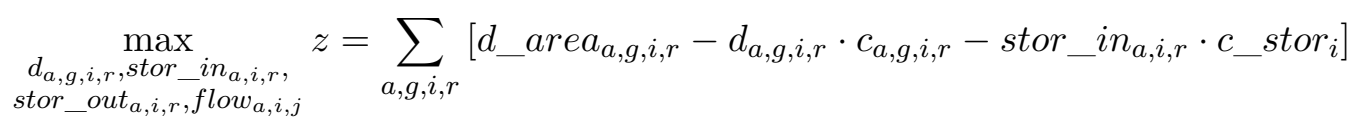

This welfare maximization approach is solved subject to several constraints. The demand constraints guarantee that certain minimum and maximum water deliveries are met in every period. Minimum water levels exist for domestic, industrial and irrigation supplies. Maximum water levels are included to ensure that no unrealisticaly high water levels are extracted at a node.

$$
\begin{array}{rlr}
d_{a, g, i, r}-d \_\min _{a, g, i} \geq 0 & \forall & a, g, i, r \\
-d_{a, g, i, r}+d \_\max _{a, g, i} \geq 0 & \forall & a, g, i, r
\end{array}
$$

The flow constraints ensure a minimum river flow for environmental reasons as well as a maximum possible flow due to specific river basin characteristics.

$$
\begin{aligned}
& \text { flow }_{a, i, j}-f \_\min _{i, j} \geq 0 \quad \forall \quad a, i, j \\
& - \text { flow }_{a, i, j}+f \_\max _{i, j} \geq 0 \quad \forall \quad a, i, j
\end{aligned}
$$

The first storage constraint ensures that the net storage is always zero or positive; thus no more water can be extracted than what has been stored in the periods before. Another constraint assures that the maximal storage basin containment is not exceeded. We 
therefore introduce $b$ as an alias of $a$.

$$
\begin{gathered}
\sum_{b: b \leq a}\left(s t o r \_i n_{b, i, r}-s t o r \_o u t_{b, i, r}\right) \geq 0 \quad \forall \quad a, i, r \\
-\sum_{b: b \leq a}\left(s t o r \_i n_{b, i, r}-s t o r \_o u t_{b, i, r}\right)+s t o r \_\max _{i} \geq 0 \quad \forall \quad a, i, r
\end{gathered}
$$

All players are linked via the flow balance which sums up out- and incoming flows, demand outflows, demand return flows of upstream nodes from the previous period, natural inflows (e.g. effective precipitation), natural outflows (e.g. evaporation) as well as the difference of in- and outflows from storage facilities representing change in storage at each node $i$ in every period $a$.

$$
\begin{aligned}
& \sum_{j} \text { flow }_{a, i, j}-\sum_{j} \text { flow }_{a, j, i}+\sum_{g, r} d_{a, g, i, r}-\sum_{j, g, r}\left(d_{a-1, g, j, r} \cdot \text { return }_{g}\right)-\text { prec }_{a, i}+\operatorname{evap}_{a, i} \\
& +\sum_{r}\left(\text { stor_in }_{a, i, r}-\text { stor_out }_{a, i, r}\right)=0 \quad \forall \quad a, i
\end{aligned}
$$

This model is formulated as a Quadratically Constrained Problem and solved with the solver CPLEX and the General Algebraic Modeling System (GAMS). It is scalable and can easily be enlarged (e.g. increasing its number of periods as well as nodes) or adjusted (e.g. focussing on specific regions or sectors). However, all presented scenearios in this paper are run with the same settings to enable a better comparison in between them.

\section{Data Analysis}

\subsection{Water Demand in the Tigris Euphrates Rivershed}

\subsubsection{The Demand Function}

The objective function is maximizing the welfare. This approach therefore depends on the sectoral demand and cost function for water in each node. The slope $m_{a, g, i}$ of the linear demand function is calculated as result of the reference price $p \_r e f_{g, i}$, the reference demand values $d \_r e f_{a, g, i}$ as well as an assumed sectoral elasticity parameter $\eta_{g}$.

$$
m_{a, g, i}=\frac{p \_r e f_{g, i}}{\eta_{g} \cdot d \_r e f_{a, g, i}} \quad \forall a, g, i
$$

The required demand elasticity of the agricultural sector is taken from GiBBOns (1986) and the ones for the industrial and domestic elasticity from HEERDEN ET AL. (2008). 
Table 2: Elasticity of different sectors

\begin{tabular}{l|ccc}
\hline Country/Sector & Agriculture & Households & Industry \\
\hline Elasticity & -0.25 & -0.3 & -0.2 \\
\hline
\end{tabular}

Source: Gibbons (1986) and HeERden Et AL. (2008)

The intercept $n_{a, g, i}$ of the linear demand function is then being calculated as a result of the slope $m_{a, g, i}$, reference price $p \_r e f_{g, i}$ and the reference demand values $d \_r e f_{a, g, i}$.

$$
n_{a, g, i}=p \_r e f_{g, i}-d \_r e f_{a, g, i} \cdot m_{a, g, i} \quad \forall \quad a, g, i
$$

Sectoral reference demand values are published on a national level by the Food and Agriculture Organization of the United Nations (FAO) in their Water Report 34 (FAO, 2009a). These national figures are then broken down to regional reference demand figures according to the current number of inhabitants, existing farm lands and industrial facilities in the specific regions (World GAZETTEeR, 2010). Back flow figures and irrigation efficiency values were used to calcultate an even more precise reference demand in the agricultural sector (KuCUkmenmetoglu, 2009). We split the annual reference demand in the ratio of $3: 1$ for the agricultural sector, as the agricultural demand does not coincide with the irrigation requirements of the basin (Akanda et al., 2007). An even distribution is assumed for both seasons for the industrial and domestic sector (KuCUkmeHmetoGLU, 2009).

Assessing the reference price for various sectors and regions is relatively difficult as it depends on the definition of the applied water price: Therefore, one has to decide between taking the charged price to the consumer, the supply costs or even the full economic costs of water. A calculation of the supply costs would include the costs of operation and maintenance as well as the investment and opportunity costs. For economic costs we would have to add resource costs, if water is economically scarce, as well as possible environmental damage costs connected to the water usage. The price that is being paid by the consumer is however almost nowhere anything close to the supply cost of water, let alone its economic costs. Water prices in the Middle East in specific are relatively low; sometimes even below mobilization costs, and thus do not reflect its scarcity. The fast population growth has led politicians to subsidize water to satisfy the need for additional irrigation purposes, especially since the 1960s and 1970s. (WARD AND Michelsen, 2002 as well as INECO, 2009). The following section describes the assumptions taken to calculate a reference price for the different sectors and regions.

To estimate the parameters of the demand functions we furthermore need the reference prices for each node and sector. If water is an intermediate good used for production processes such as farming, the average value of water can be measured indirectly by the monetarized value of the output and the quantity of water necessary to produce this output. The Aquastat Database from the FAO (2009a) and Frenken (2009) provide data on the size of cultivated land and on the total value of agricultural products for each 
country whereas Beaumont (1998) and MunlaHasan (2007) contains good estimates for total annual water need for irrigation in the agricultural sectors of all three countries. This allows for calculating the value of water in the agricultural sector as a ratio of:

$$
\text { Agr water value }\left[\$ / m^{3}\right]=\frac{\text { total value of products }[\$]}{\text { total irrigated area }[\text { ha }] \cdot \text { water tarif }\left[\mathrm{m}^{3} / \mathrm{ha}\right]}
$$

This approach accounts for welfare creation at the moment of water usage and not at the moment of selling the final products on the market. Turkey is creating the highest profit with $0.066 \$ / \mathrm{m}^{3}$, compared to Syria with $0.057 \$ / \mathrm{m}^{3}$. The existing data sets for the country of Iraq are inconsistent due to different years of data retrieval. Therefore, we use the figure of $0.025 \$ / \mathrm{m}^{3}$ proposed by Kucukmenmetoglu (2009).

Measuring the value of water in the domestic sector requires a different approach. Here, the price, i.e. water tariffs for consumption of small households with less than $15 \mathrm{~m}^{3} / \mathrm{month}$ were used to approximate the marginal value of $1 \mathrm{~m}^{3}$ water in the low consumption segment. The water tariff survey by the Global Water Intelligence (GWI, 2010) gives detailed data on water rates in 276 cities around the world. For the the TE-region, the tariffs mostly lie in a range between $0.05 \$ / m^{3}$ (Damascus, Syria) and $1.79 \$ / m^{3}$ (Gaziantep, Turkey). Such high variances are influenced by cultural and political incentives to keep the water price low and do not neccessarily resemble the real differences in water supply costs (CAKMAK, 2010). We assume a unified average value of water of $1 \$ / \mathrm{m}^{3}$ for the domestic sector in all countries.

Finally, the value of water in the Syrian industrial sector is taken from INECO (2009). This tariff of $0.65 \$ / \mathrm{m}^{3}$ is applied for all three countries due to a lack of more precise data for the other two countries. All water values are furthermore assumed to be independent of the season.

\subsubsection{Range of demand and return flows in different sectors}

For all three sectors, minimum and maximum demand figures were calculated to provide valid boundaries for the decision variables. In the agricultural sector, maximum demand is calculated from the total amount of irrigable area times annual water need for irrigation. The total amount of irrigable land has been derived from GAP (2006), CAKMAK ET AL. (2005), Yenigun and Aydogdu (2010), Bagis (1997), Beaumont (1998), Hole AND ZAITCHIK (2007), ARDI (2006), and KUCUKMEHMETOGLU (2009) including current irrigation areas as well as the potential enlargements. The annual water need value is again taken from Beaumont (1998). The minimum demand figures are derived by assuming a minimum quantity of two percent of the maximum figures.

The average domestic water consumption in Iraq per inhabitant currently accounts for 120-1601/day (REPUBLIC OF IRAQ, 2006). This is much below the one of other countries, e.g. an Israelian household with 2801 per person/day, facing a similar climate (STATE OF IsRAEL, 2002). The maximum demand is based on a household in the United Arab Emirates, having the highest listed average consumption per inhabitant in this region with 5501 per day (equivalent to $200 \mathrm{~m}^{3} / y$ ) (UAE, 2008). The minimum demand in the domestic sector per inhabitant has been defined to be 401 per day (equivalent to $15 \mathrm{~m}^{3} / \mathrm{y}$ ) according to the water poverty threshold developed by the WHO and UNICEF (WATKINS, 2006). 
Multiplying the above demand values by the population of the respective regions (WORLD GazetTEer, 2010) yields the yearly input data for each node.

The maximum demand in the industrial sector corresponds to the doubling of the reference demand. The minimum demand figures are derived by assuming a minimum quantity of 15 percent from the reference demand. The demand values in the domestic and industrial sector are supposed to remain unaffected by seasons.

The model also incorporates return flows into downstream nodes one period after the original use of the water. They resemble 35 percent of the original flow in the agricultural and 80 percent in the industrial and domestic sector according to KUCUKMEHMETOGLU (2009).

\subsubsection{Costs of the Different Sectors}

The costs for agricultural water supply in Turkey and Syria are taken from CAKMAK (2010) and INECO (2009), respectively. We assume the same costs for Syria and Iraq. The annual water tariff for irrigation from Beaumont (1998) and MunlaHasan (2007) can then be used to express the costs in terms of cubic meter. The unit costs for the agricultural sector are given in table 3 and are assumed to be independent of season. Based on KuCUkmenmetoglu (2009) the model computes supply costs in the domestic and industrial sector depending on the distance from the nearest river, with a cost term of $0.005 \$ / \mathrm{m}^{3}$ per $\mathrm{km}$.

Table 3: Costs of $1 m^{3}$ water in the agricultural sector per country [\$]

\begin{tabular}{l|c}
\hline Country & Agricultural Costs \\
\hline Iraq & 0.0060 \\
Syria & 0.0075 \\
Turkey & 0.0083 \\
\hline
\end{tabular}

Source: Own calculations based on Beaumont (1998), Ineco (2009), MunlaHasan (2007), and CAKMAK (2010).

\subsection{River Data for the Tigris, Euphrates, and its Tributaries}

\subsubsection{Inflow Data}

Water data on the TE-basin varies considerably throughout numerous studies which were carried out. All presented data in this section is based on own estimates originating from Beaumont (1998), Erdem (2002), Kavvas et Al. (2011), Kolars (1994), Sener (2007) and SHAhin (1989). The problem of non-comparable data steams from applying different methods for water quantity assessments. In addition to that, some information is also not made publicly accessible, due to a political value of water information as bargaining chip in allocation negotiations between parties.

The Euphrates river basin has a surface of $450,000 \mathrm{~km}^{2}$. The length of the river is approaximately $2,700 \mathrm{~km}$ and is, due to upstream rapids and shoals, only navigable by very 
light rafts up to the Iraqi city of Hit. Its water levels start to increase from February onwards, due to spring rains, and reaches its maximum in April and May. From July onwards monthly flows can sometimes go down to two percent of its original maximum flow. The Euphrates has a total flow of 12 to $60 \mathrm{bcm} /$ year but most of the times ranges from 29 to $35 \mathrm{bcm} /$ year. More than 90 percent of this runoff is contributed by Turkey, while the remaining water enters through the Syrian tributaries Khabur (1.5 bcm/year), Belikh (0.2 bcm/year) and Sajur (0.1 bcm/year).

As different as the countries are from another, so are the Tigris and Euphrates. Both rivers have high seasonal as well as yearly variations, which are not necessarily correlated, though. Therefore, in the past Iraq was able to compensate lower water levels of the Euphrates (due to draughts or higher upstream extractions) by additional irrigation through water resources from the Tigris watershed. Due to the rapid population increase in the basin it is, however, unclear how long this is going to be possible.

The Tigris River is approaximately $1,800 \mathrm{~km}$ long and is navigable by larger vessels to Baghdad and by light rafts upstream to Mosul. Its basin covers a surface of 375,000 $\mathrm{km}^{2}$ and profits from a longer and earlier raining period than the Euphrates. The Tigris reaches its maximum flow from March through May, accounting for more than 50 percent of the mean annual flow. Minimum flow conditions can be observerd from August through October summing up to only seven percent of the mean annual flow. As for the total water potential of the Tigris, values can range between 21 to $72 \mathrm{bcm} /$ year but mostly vary in between 48 and $53 \mathrm{bcm} /$ year. Around 45 percent of the water originates from Turkey, while another 45 percent come from the Iraqi tributaries Greater Zab (13.2 bcm/year), Lesser Zab (7.2 bcm/year), Adhaim (0.8 bcm/year) and Diyala (5.7 bcm/year). Another, third, main tributary of the TE-Watershed is the Karkheh $(6.3 \mathrm{bcm} /$ year $)$ which springs in Iran and accounts for the remaining ten percent of inflow.

We assume inflow values of $32 \mathrm{bcm} /$ year (90\% Turkey, $10 \%$ Syria) for the Euphrates and $50 \mathrm{bcm} /$ year for the Tigris (45\% Turkey, $45 \%$ Iraq, $10 \%$ Iran) as these have been the average values in the last decades. Both rivers are aggregated into a six months rainy and dry season, based on their monthly variations. Examining their monthly flows, a ratio of $7: 3$ is chosen as multiplier for the volume of all rivers, with $70 \%$ of the water falling during the rainy season. Including a minimum outflow at the Shatt Al-Arab, accounting for $25 \%$ of the combined virgin flows of Euphrates and Tigris, ensures a minimum flow throughout the basin for navigational and environmental reasons. See table 9 in the Appendix for the seasonal inflow data. Various nodes have no additional tributary inflow, but function only as transport nodes for modeling the river flow.

\subsubsection{Storage and Evaporation}

A lot of dams were recently built or are currently under construction in the TE-Watershed. Many constructions have been paused for several years already, though and it is very difficult to find exact data, especially for smaller dams. For that reason, only the largest already completed dams have been selected and attributed to their neighbouring nodes. Water evaporation is another immanent problem in warm regions and especially the constructio of dams is leading to high water losses at the storage reservoirs. Data for storage reservoirs and their evaporation figures have been derived from BEAUMONT (1998) for 
Turkey and from Kavvas ET AL. (2011) for Syria and Iraq (see table 4). Yearly evaporation figures for all reservoirs have been assumed to occur with 60 percent during the dry season and 40 percent during the rainy season. (Kucukmenmetoglu, 2009)

Table 4: Evaporation and storage capacity at the transportation nodes [mcm/season]

\begin{tabular}{l|l|ccc}
\hline Node & Dam & Storage Capacity & \multicolumn{2}{c}{ Evaporation } \\
\cline { 3 - 4 } & & & rainy & dry \\
\hline t1 & Ataturk, Birecik, Karakaya, Kerban & 15250 & 252 & 378 \\
t3 & Abbu Dibbis, Mosul, Bekme & 22900 & 1308 & 1962 \\
t4 & Derbendikhan & 2150 & 72 & 108 \\
t5 & Dokan & 4150 & 176 & 264 \\
t6 & Thartar, Adheem & 37075 & 1280 & 1920 \\
t7 & Hamrin & 1975 & 248 & 372 \\
t8 & Kralkizi, Batman & 42000 & 440 & 660 \\
t10 & Tishreen, Tabqa, Baath & 6870 & 520 & 780 \\
t11 & Khabour & 2150 & 64 & 96 \\
t13 & Haditha & 4100 & 432 & 648 \\
t14 & Habbaniya & 1650 & 452 & 678 \\
\hline
\end{tabular}

Source: Own calculations based on Beaumont (1998) and Kavvas et AL. (2011).

Estimates for lifetime delivery costs for large storage projects including the present value capital as well as operation and maintenance costs over the economic life of the technologies vary from $2-32 \$ / 1000 m^{3}$ (KELLER ET AL., 2000). For our calculations, however, only marginal costs are of interest as capital costs are considered as sunk costs. Costs for storing water in reservoirs in Iraq and Syria are set to $1 \$ / 1000 \mathrm{~m}^{3}$ while assuming higher labour costs and stricter security standards in Turkey leading to costs of $1.5 \$ / 1000 \mathrm{~m}^{3}$.

\section{Description of Scenarios}

\subsection{Different Levels of Cooperation}

Three different cooperation levels are modeled for each scenario. The first approach represents an omniscient planner that maximizes the overall welfare for all three countries altogether. This Joint run therefore always creates the highest possible total welfare values and can be used as reference point for the other scenarios.

One further option is running the model in three sequential steps, once for each riparian country, in order of their geographical position. Turkey thus tries to maximize its own welfare, passing all remaining water quantities to Syria. Syria afterwards uses as much of this remaining water as possible, leaving even lower water quantities for Iraq. This second approach is relatively close to real-life not cooperative river usage and further onwards be referred to as Strategic approach.

The last approach assumes strategic behaviour by all countries but includes specific water treaties between borders which have to be met at all times. Several bilateral agreements 
exist to regulate the transboundary water flows in the TE-basin. A protocol has been signed in 1987 by Turkey and Syria, stating a minimum monthly release of $500 \mathrm{~m}^{3} /$ second (a bit more than half of the Euphrate's mean volume) at their border. The downstream segment of the Euphrates is regulated via a bilateral agreement of Syria and Iraq since 1990. This agreement states that 58 percent of the Euphrates water entering Syria has to be passed on to Iraq. There still does not exist any treaty regarding the flows of the Tigris, and experts also highly question the compliance of the other treaties from all sides, especially in the last politically very unstable times. (KAYA, 1998, KibArogLU, 2007, and LEB, 2010) This Treaty scenario depicts water treaties of minimum transboundary flows of 60 percent of the original inflow, including also backflows, at each border for the Euphrates as well as for the Tigris.

\subsection{Different Scenario Assumptions}

The Business as Usual $(B A U)$ scenarios are used as reference point for the other three scenarios sets. It depicts the current situation in the basin with all described input data from the previous sections. The filling of the Atatürk Dam caused huge debates as Turkey stopped the water flows to Syria from January $13^{\text {th }}$ till February $12^{\text {th }}$ in 1990 . The Turkish government was referring to the Article 6 in the protocol, allowing them to reduce the flows temporarily as long as the quantities are passed on in the following month. This sudden water flow reduction, however, led to reduced hydroelectric production in Syria and to additional agricultural losses of 15 percent in Iraq. (KAYA, 1998, KiBAROGLU, 2007, and LEB, 2010) The GAP scenarios therefore model the effects when filling a newly constructed dam in the Turkish Euphrates, which might lead to a 30 percent decrease of the annual flow (AKANDA ET AL., 2007 as well as KibAroglu AND ÜNver, 2000).

A major challenge for this region is the ongoing population growth in all countries, leading to additional water demand. The Growth scenario therefore tries to analyse possible water allocation problems beyond 2030. Annual country-specific population growth figures varying between two to four percent were taken from World GazetTeER (2010) and used to calculate future domestic water tariffs. The industrial demand is more difficult to predict as consumption is likely to rise due to economic growth, but so is its efficiency. We therefore assume industrial consumption to remain constant over time. The completion of the GAP project will lead to addional 1.7 million ha of irrigable Turkish fields in the coming years. Further future irrigation needs for 0.64 million ha in Syria and 0.5 million ha in Iraq were taken from BERKUN (2010). These predictions for additional irrigation areas were used to calculate the future agricultural reference demand for each country in the Growth scenarios.

Growth \& GAP $(G \& G)$ is the last scenario set, being a combination of the two latter. A list of all twelve scenarios can be seen in table 5 . 
Table 5: List of all scenario runs

\begin{tabular}{|c|c|c|c|c|c|}
\hline Nr. & Cooperation Level & Scenario Run & Nr. & Cooperation Level & Scenario Run \\
\hline $1 \mathrm{a}$ & Joint & \multirow{3}{*}{$\mathrm{BAU}$} & $3 a$ & Joint & \multirow{3}{*}{ Growth } \\
\hline $1 b$ & Strategic & & $3 \mathrm{~b}$ & Strategic & \\
\hline $1 c$ & Treaty & & $3 \mathrm{c}$ & Treaty & \\
\hline $2 \mathrm{a}$ & Joint & \multirow{3}{*}{ GAP } & $4 a$ & Joint & \multirow{3}{*}{$G \& G$} \\
\hline $2 \mathrm{~b}$ & Strategic & & $4 \mathrm{~b}$ & Strategic & \\
\hline $2 c$ & Treaty & & $4 \mathrm{c}$ & Treaty & \\
\hline
\end{tabular}

Source: Own illustration of scenarios.

\section{Results and Interpretations}

\subsection{Results of the Different Scenarios}

\subsubsection{BAU and GAP Scenarios}

The outcomes of the BAU-model runs in figure 3 and 4 show that the agricultural sector is responsible for the smallest welfare share, even though it has the highest demand share throughout all nations and seasons. The domestic and industrial sector have similar water efficiencies. The demand and welfare figures of Iraq are strikingly high and are due to the fact that the majority of the TE-basin lies inside the territory of Iraq. These absolute figures should therefore not be over-interpreted as later results prove that Iraq is in fact the least efficient user of water in this region.

The domestic and industrial sectors in all countries and all seasons offer a higher return rate than using the water for irrigation purposes. Therefore, in case of low water flows in a region, only the minimum agricultural water demands are met. With increasing water supply more and more remaining water quantities are used for irrigation purposes. Irrigation is mostly done in the summer, leading to higher agricultural water demands in the dry season. The Iraqi agriculture sector is the least effective, but still receives a relatively big share of water. This is due to the fact that the water of the Tigris river directly passes from Turkey to Iraq and is thus not accessable for Syria. Also, Iraq's disposes of tributary inflows to the Tigris river account for 55 percent of the total Tigris water flow. The Iraqi industrial sector is having twice as high demand needs as the domestic sector. The opposite is true for Turkey as well as Syria, which are both lacking bigger industrial complexes along the TE-rivershed.

The BAU scenarios assume an average inflow of both rivers, no demand growth as well as perfect foresight. Thus only slight changes are visible in between the different levels of cooperation. The shifting of agricultural usage on the Euphrates from the Iraqi fields $(-0.34$ bil.\$) to Syrian $(+0.12$ bil.\$) and Turkish $(+0.05$ bil.\$) grounds leads to an overall welfare loss of 0.4 percent. 

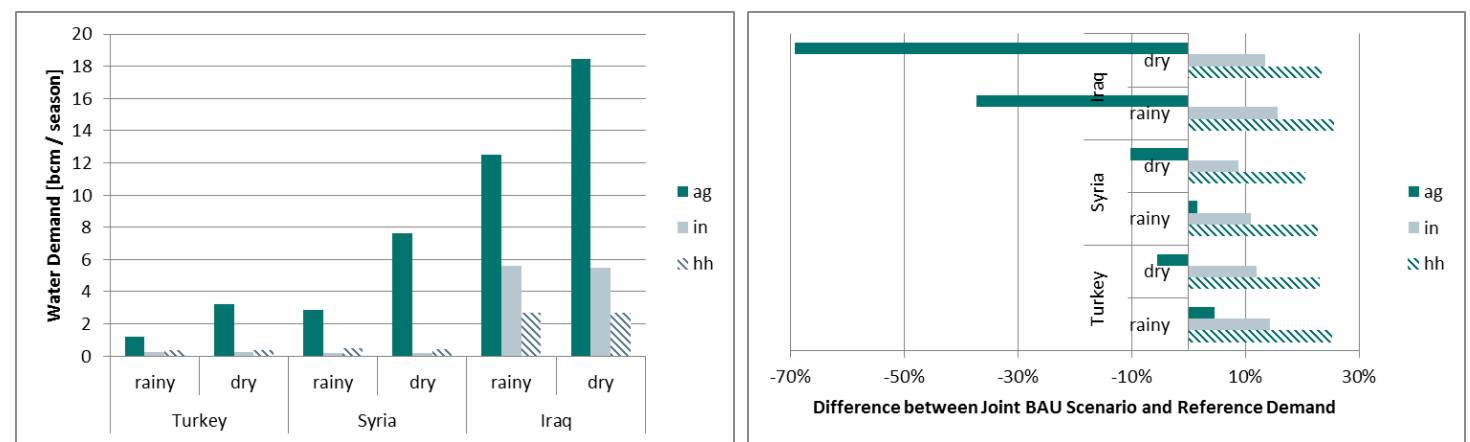

Figure 3: Demand distribution assuming a joint water allocation for the BAU scenario and comparison to its reference demand

Source: Own illustration based on the results of the WATER-Model

Figure 4: Welfare distribution in the BAU scenario assuming a joint water allocation

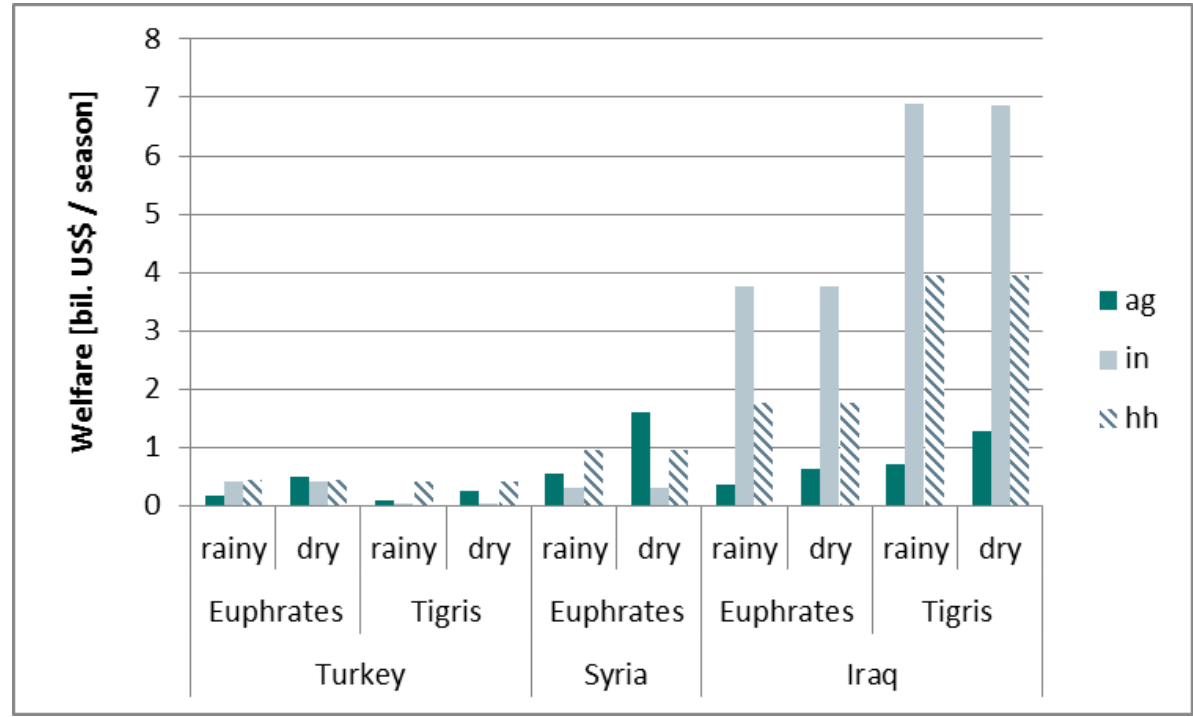

Source: Own illustration based on the results of the WATER-Model 
The exogenous filling of a reservoir in the Turkish part of the Euphrates leads to additional water scarcity in the GAP scenarios. As this additionally stored water does not produce any direct value in the model, the overall welfare is reduced compared to the BAU scenarios. A comparison of the Turkish welfare figures between the BAU and the GAP scenarios assuming strategic behaviour however shows that they have hardly changed. The additionally stored water instead origins from the share of the Iraqi downstream regions. Such a shift in water consumption decreases the overall welfare by 7 percent in comparison to a joint water allocation. This decrease of overall welfare is caused by water being used for the less beneficial upstream Turkish agricultural sector instead of the domestic and industrial Iraqi sector.

\subsubsection{Growth and G \& G Scenarios}

The welfare figures of the Growth and the G \& G scenarios are much higher due to the increasing water demand beyond 2030. A comparison among all four scenario types can therefore only be done by comparing relative and not absolute figures.

The water consumption of the Turkish and Syrian domestic and industrial sector remains nearly the same in all three Growth scenarios. In Iraq, however, a strong reduction throughout all sectors along the Euphrates can be observed when strategic behaviour is being modelled. These missing water volumes, as well as smaller amounts from the Syrian agricultural sector, are being used by the upstream Turkish agricultural sector. This leads to an overall welfare reduction of 9.6 percent for the whole basin in case of strategic behaviour.

The analysis of the usage of reservoirs in the different countries shows, how the storage capacities of Syria and Iraq can reduce the effects of strategic behaviour. Strategic behaviour of Turkey decreases the inflow figures for the Tigris into Iraq. Iraq, however, manages to compensate most of this effect by storing its water reserves for the dry period. A stronger usage of Iraqi reservoirs on the Tigris of 50 percent in the BAU scenarios and 30 percent in the Growth scenarios can therefore be observed in case of strategic behaviour (see figure 5). These storage options, as well as the Iraqi inflows into the Tigris, result in lower welfare losses for the Tigris compared to the Euphrates basin. 
Figure 5: Total storage in the ET-basin for the BAU and Growth scenarios

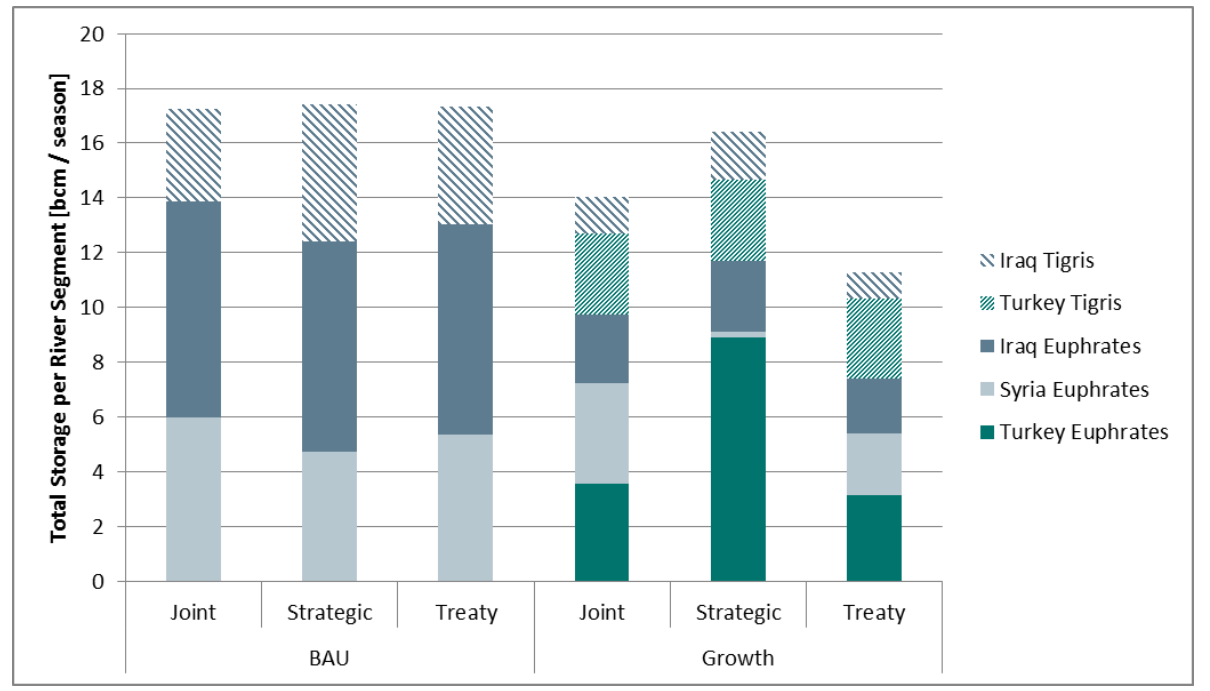

Source: Own illustration based on the results of the WATER-Model,

The model is run under the assumption of perfect foresight. Therefore, no storage usage can be seen in the Turkish reservoirs in the BAU scenarios, as inflow values are at all times sufficient to meet the sectoral demands. It is only in the Growth scenarios, esp. when assuming strategic behaviour, that due to the additional demand in the Turkish area, Turkey starts using its reservoirs to meet its high demands during the dry period. Turkey's usage of its reservoirs leads to water scarcity in the downstream regions and lower usage of Iraqi and Syrian reservoirs. There is nearly no water being stored by Syria in the strategic Growth scenario as most of the water is being consumed directly. Syria, however, does have some own minor tributaries to supply itself with water in the dry period. Iraq is without any own tributaries on the Euphrates. It therefore continues saving water reserves in the rainy period, to meet its minimum demand levels in the following dry period (see figure 5).

Similar as in the GAP scenarios, the filling of the dam in the G \& G scenarios leads to additional water scarcity in the basin and a reduction of the overall welfare compared to the Growth scenarios. In this case, however, when assuming strategic behaviour, also shifts in the Turkish demand can be observed. No further water can be extracted from the Iraqi share, as their quantities had already reached the minimum thresholds in the Growth scenarios. The additionally stored water origins from the Turkish agricultural and all Syrian sectors.

The welfare distribution alongside the Euphrates river in all G \& G scenarios can be seen in figure 6. Strategic behaviour of Turkey in the $G \&$ \& scenario leads to an increase of its welfare by 20 percent but reduces the welfare of Syria (-70 percent) and Iraq (-40 percent). The overall welfare loss in the Euphrates basin sums up to 33 percent, while only reaching 14 percent across both river basins, as the Tigris is not as much affected by strategic actions. 
Figure 6: Welfare distribution in the Euphrates basin for the G \& G scenarios

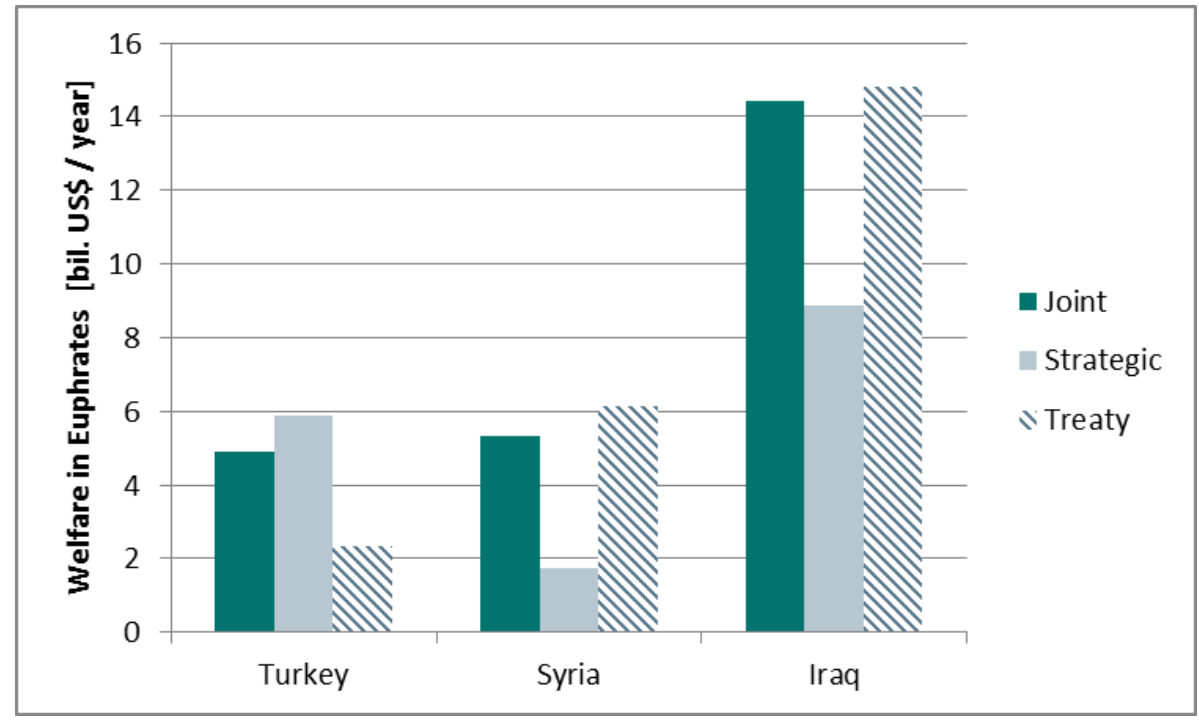

Source: Own illustration based on the results of the WATER-Model

\subsection{Summary of all Scenarios}

Table 6 summarizes the main welfare effects of the different scenarios across the river basin. Examining the different scenarios it becomes visible that strategic behaviour does not cause high welfare losses in the BAU scenarios. It is only when additional water scarcity is being caused through the filling of dams (GAP scenario: -7 percent welfare loss) or a demand growth (Growth scenario: -9.6 percent welfare loss), that strategic actions influence the overall welfare. Iraq is the looser of such events, as it is located at the downstream part of the rivershed. This becomes even more visible, when a higher scarcity of water leads to a reduction of water not only in its agricultural, but also in the domestic and industrial sectors. 
Table 6: Overall welfare in all scenario runs [bil. \$/year]

\begin{tabular}{|ll|ccc|c|c|}
\hline & & Turkey & Syria & Iraq & Total Welfare & Change \\
\hline BAU & Joint & 4 & 5 & 36 & 44 & \\
& Treaty & 4 & 5 & 35 & 44 & $-0.2 \%$ \\
& Strategic & 4 & 5 & 35 & 44 & $-0.4 \%$ \\
\hline GAP & Joint & 4 & 5 & 35 & 43 & \\
& Treaty & 3 & 4 & 35 & 43 & $-0.7 \%$ \\
& Strategic & 4 & 5 & 32 & 40 & $-7.0 \%$ \\
\hline Growth & Joint & 11 & 7 & 44 & 62 & \\
& Treaty & 10 & 6 & 45 & 61 & $-0.9 \%$ \\
& Strategic & 12 & 5 & 39 & 56 & $-9.6 \%$ \\
\hline \multirow{6}{*}{ G \& G } & Joint & 10 & 5 & 44 & 59 & \\
& Treaty & 7 & 6 & 45 & 58 & $-2.7 \%$ \\
& Strategic & 11 & 2 & 39 & 51 & $-13.8 \%$ \\
\hline
\end{tabular}

Source: Own calculations with the WATER-Model.

The results point out, that most of the welfare losses, caused by strategic behaviour, can be evened out when implementing water treaties between countries. This reduces the welfare loss to figures below one percent in the GAP and Growth scenarios. However, this does not hold for each player individually: Turkey is observing lower welfare figures, when giving up its strategic advantage and sticking to agreed on treaties, while Iraq profits from minimum water treaties. Syria, on the other hand, is loosing minor welfare shares in the GAP scenario, but highly profits from such treaties in the Growth and G \& G scenarios, due to the rising Turkish demand.

The overall welfare in case of water treaties is still slightly below the joint optimization runs. The main reason for this is, that implementing minimum flow treaties of 60 percent enables further Iraqi agricultural downstream usage. This sector, however, is less efficient in water usage, causing lower overall welfare figures, compared to using this water in other countries.

It is especially the regions in the Euphrates delta that are suffering from the higher water extractions in the upstream area. Examining the repartition of welfare in between the two rivers, as done in figure 7 for the G \& G scenarios, shows the dependence of Iraq on the Tigris. The Iraqi Tigris river is much more independent as Syria is having no access to it and half of the Tigris' water springs in Iraqi territory. Therefore, also the majority of its industrial sites are grouped along the Tigris and its tributaries. Water volumes from the Euphrates had temporarily been reduced in the past due to higher water needs (e.g. due to the filling of dams) of Syria and Turkey and thus always resembled higher uncertainties for Iraq. Turkey is using water volumes from both rivers, but is having its main industrial centres along the Euphrates. In case of strategic behaviour its consumption in both rivers rises, leading to a welfare reduction in Syria. Syria, in contrast to the other two countries, is having only access to the Euphrates river and some minor tributaries which join the 
Euphrates on Syrian ground.

Figure 7: Welfare distribution in the G \& G scenarios for each river segment

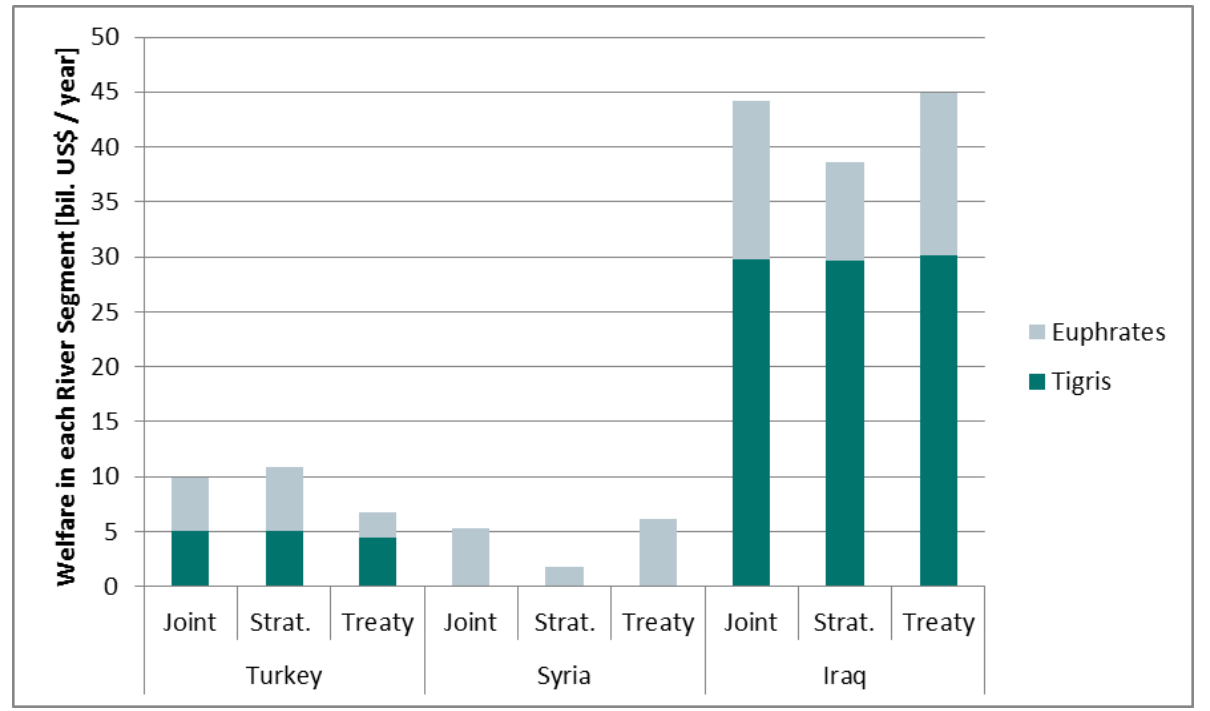

Source: Own illustration based on the results of the WATER-Model,

The agricultural sector in the WATER model is assumed to have the lowest return values for water consumption in all regions at all times. Therefore, a scarcity of water immediately causes a reduction of its consumption share up to its minimum level. Only with persistant scarcity, water from the domestic and industrial sector are being extracted. Table 7 highlights the effects of the different scenarios on the agricultural sector, which is the main driver influencing the overall welfare changes. The increasing water shares of the Turkish agricultural sector in case of strategic behaviour causes the overall welfare losses throughout all scenarios. Syria's irrigation increases in the BAU and GAP scenarios, but shrinkes sharply as soon as demand growth is assumed. Iraq's agriculture is forced to its minimum threshold already in the GAP scenario. For the Growth and G \& G scenarios constant minimal agricultural usage can be observed, while additional reductions in the domestic and industrial sector lead to further Iraqi welfare losses. 
Table 7: Agricultural welfare in the Euphrates [bil. \$/year]

\begin{tabular}{|ll|cc|cc|cc|cc|}
\hline \multirow{2}{*}{ Turkey } & & BAU & & GAP & & Growth & & G \& G & \\
& & Joint & Strat. & Joint & Strat. & Joint & Strat. & Joint & Strat. \\
& Change & 0.67 & 0.70 & 0.64 & 0.70 & 3.75 & 4.85 & 2.53 & 3.53 \\
Syria & & $5 \%$ & & $9 \%$ & & $29 \%$ & & $39 \%$ \\
& Welfare & 2.16 & 2.28 & 2.03 & 2.18 & 2.79 & 1.36 & 1.58 & 1.14 \\
& Change & & $6 \%$ & & $8 \%$ & & $-51 \%$ & & $-28 \%$ \\
\hline \multirow{2}{*}{ Iraq } & Welfare & 1.00 & 0.76 & 0.29 & 0.10 & 0.10 & 0.10 & 0.10 & 0.10 \\
& Change & & $-24 \%$ & & $-66 \%$ & & $0 \%$ & & $0 \%$ \\
\hline
\end{tabular}

Source: Own calculations with the WATER-Model.

\subsection{Various Aspects for Future Research}

Further research in river basin management and especially for this basin is needed to understand how a sustainable allocation of water resources can be accomplished to stabilize the region and to prevent violent conflicts. The scenarios were calculated assuming perfect foresight on the basis of an average river flow, despite the high variance of the annual inflows of both rivers. Incorporating stochastic variables to model the unpredictable fluctuation of the rivers would result in lower welfare figures and different strategic behaviours. Increasing the time scope of the model over several years would be useful to examine effects of dry or wet years on subsequent periods.

Further ecological constraints could be included into the WATER-Model to examine the effects of strategic behaviour on water qualities. RAHI AND HALIHAN (2010) calculate a minimum flow rate of $178 \mathrm{~m}^{3} /$ second (or $5.6 \mathrm{bcm} /$ year) for the Euphrates on the Syrian border to Iraq to preserve its environment, as salinity values would otherwise be too high in the downstream region. This value is not met in most of the model runs due to too extensive water usage in the upstream area. This is especially the case in the Growth and G \& G scenarios due to the increased Turkish demand. Including such constraints into the model would lead to a decreased welfare value as the positive environmental effects are not depicted in the model.

Tilmant And Kelman (2007) have examined the effects of increasing the current irrigation efficiency of 0.4. Including such technological improvements in the prediction of future scenarios might ease the water scarcity in the overall basement and should be more closely examined in the future. Some additional focus could also be put on on-stream water usage such as electricity production through hydropower, navigation or recreation benefits in the basin. 


\section{Conclusion}

The modeling of the Tigris-Euphrates-Watershed enables a quantification of welfare losses due to extensive water usage at the upper stream of the two rivers. Water disputes in the region clearly stem from the mismatch between demand and supply of water coupled with the uncoordinated nature of current water development projects. This becomes extremely visible in the case of the Euphrates River, where more than 90 percent of its water springs in Turkey. Calculations show that strategic behaviour of countries can lead to total disruptance of agricultural usage in downstream areas of Syria and Iraq. This also becomes visible in total welfare losses of up to 33 percent along the Euphrates, especially when incorporating the expected demand growth in the region. Turkey, being substantially higher developed than its riparian countries, is most efficient in its water usage. Passing on sufficient water for Iraqi and Syrian domestic and industrial sectors though has the potential of increasing the overall welfare of the region, but reduces the Turkish welfare. Calculations point out, that minimum flow treaties of around 60 percent of the average river flows from Turkey to Syria would be able to achieve this aim. Therefore further political measures, such as transboundary water treaties, should be negotiated and most important also be controlled to guarantee a minimum downstream flow of both rivers.

Another option to overcome dryer periods and to regulate the fluctuations of the rivers is to build further reservoirs. The Turkish "Southeastern Anatolia Project" (GAP) has planed the construction of additional 22 dams of which 15 have so far been completed. Such infrastructure project have an enormous potential for the surrounding region, but at the same time are a threat for all downstream regions which in turn become even more dependent on its upstream neighbours. Scenario outputs reveal, that especially the filling of new reservoirs can cause high welfare losses if these actions are not done on a basin-wide coordinated basis.

A sustainable joint usage of the Tigris Euphrates basin would result in high welfare increases. This could even lead to more political stability in the whole region and should therefore be fostered by all riparian countries. Such agreements, however, are needed as soon as possible, as the fast population growth leads to increasing water scarcity in the region. Water salinity figures in some parts of the Iraqi Euphrates have quadrupled in the last thirty years. Iraq, formerly known as highly fertile and productive Mesopotamia, meanwhile suffers under an increased deterioration of its marshlands. A recoupment of its farmlands, however, does have the potential for creating thousands of uneducated jobs, leading to a higher political stability of the whole area. It should therefore be in the interest of institutions such as the World Bank and the EU to promote cooperation in between all adjacent countries. The ratification of the UN Convention on the Law of Non-Navigable Uses of International Watercourses might be an important next step in such a process. However, Instruments such as additional loans for the finalization of the GAP project have to be found to reward and compensate Turkey for guaranteeing certain minimum water releases to its downstream neighbours. 


\section{References}

Akanda A, Freeman S, Placht M (2007) The Tigris-Euphrates river basin: mediating a path towards regional water stability. The Fletcher Sch J For Issues Relat To Southwest Asia And Islamic Civiliz:1-12

Allan JA (2002) The Middle East water question: hydropolitics and the global economy. Vol. 2. I.B. Tauris Publishers, London, New York

ARDI (2006) Strategy for Water and Land Resources in Iraq. Agriculture Reconstruction and Development Program for Iraq. USAID. Final Report. USA.

Bagis AI (1997) Turkey's hydropolitics of the Euphrates-Tigris basin. Water Resour Dev $13: 567-581$

Beaumont P (1998) Restructuring of water usage in the Tigris-Euphrates basin: the impact of modern water management policies. In: Coppock J, Miller JA (1998): Transformation of Middle Eastern natural environments: legacies and lessons, Bulletin Series of Yale School of Forestry and Environmental Studies 103, pp. 168-186

Berkun M (2010) Hydroelectric potential and environmental effects of multidam hydropower projects in turkey. Energ For Sustain Dev 14:320-329

Brouwer R, Hofkes M (2008) Integrated hydro-economic modelling: approaches, key issues and future research directions. Ecol Econ 66:16-22

Brown O, Crawford A (2009) Rising temperatures, rising tensions: climate change and the risk of violent conflict in the Middle East. International Institute for Sustainable Development (IISD). http://www.iisd.org/pdf/2009/rising_temps_middle_east. pdf. Accessed 04 October 2013

Cagaptay S (2012) The empires strike back. The New York Times (Sunday Review), 14 January 2012. http://www.nytimes.com/2012/01/15/opinion/sunday/the-empiresstrike-back.html? pagewanted=all\&_r=0. Accessed 04 October 2013

Cakmak EH (2010) Agricultural water pricing: Turkey. Organisation for Economic CoOperation and Development (OECD). http://www.oecd.org/turkey/45016347.pdf. Accessed 01 September 2013

Cakmak EH, Kanber R, Koc DL, Önder D, Tüzün M, Ünlü, M (2005) Unconventional irrigation water use in Turkey. In: Hamady A, El-Gamal F, Lamaddalena N, Bogliotti C, Guelloubi R (eds) Non-conventional water use: WASAMED Project. Proceedings of the 3rd WASAMED workshop, 07-10 December 2004, Cairo, pp 129-140

CGM (2012) The lost rivers of the Garden of Eden. http://www.kjvbible.org/rivers_of_ the_garden_of_eden.html. Accessed: 04 June 2012

Daoudy M (2009) Asymmetric power: negotiating water in the Euphrates and Tigris. Int Negot 14:361-391 
Davis DW, Hanbali FU, McPherson MM (2004) Interagency cooperation in an international program: USACE-HEC hydrologic modeling for the Tigris and Euphrates in support of USAID-Reconstruction Program in Iraq. US Army Corps of Engineers Hydrologic Engineering Center.

Dinar S (2012) The geographical dimension of hydro-politics: international freshwater in the Middle East, North Africa and Central Asia. Eurasie Geogr And Econ 53:115142

Dinar A, Dinar S, McCaffrey S (2007) Bridges over water: understanding transboundary water conflict, negotiation and cooperation. World Scientific, New Jersey

Elhance A (1999) Hydropolitics in the Third World: conflict and cooperation in international river basins. US Institute of Peace Press, Washington DC

Elver H (2002) Peaceful uses of international rivers: the Euphrates and Tigris dispute, Vol. 07. Transnational Pub Inc, New York

Erdem M (2002) The Tigris-Euphrates rivers controversy and the role of international law. Percept (Ank) 8:91-119

Evans JP. (2009) 21st century climate change in the Middle East. Clim Chang 92:417-432

FAO (2009a) AQUASTAT-Database. Syria, Turkey, Iraq. Food and Agriculture Organization of the United Nations (FAO). http://www.fao.org/nr/water/aquastat/ basins/euphrates-tigris/index.stm Accessed 04 October 2013

FAO (2009b) Map of Euphrates-Tigris river basin. Food and Agriculture Organization of the United Nations (FAO). http://www.fao.org/nr/water/aquastat/basins/ euphrates-tigris/figure03.pdf\#fig3 Accessed 04 October 2013

Frenken K (2009) Irrigation in the Middle East region in figures- AQUASTAT Survey 2008. Water Reports 2009, No. 34. ftp://ftp.fao.org/docrep/fao/012/i0936e/ i0936e00.pdf. Accessed 04 September 2013

GAP (2011) GAP action plan. Republic Of Turkey Ministry Of Development Southeastern Anatolia Project Regional Development Administration. http://www.gap.gov.tr/ english. Accessed 03 June 2012

GAP (2006) Latest situation on Southeastern Anatolian Project- activities of the GAP administration. Republic Of Turkey Ministry Of Development Southeastern Anatolia Project Regional Development Administration. http://includes.gap.gov.tr/ files/ek-dosyalar_en/about-gap/latest-situation.pdf. Accessed 04 October 2013

Geopolicity (2010) Managing the Tigris Euphrates watershed: the challenge facing Iraq. http://geopolicity.ae/upload/content/pub_1293090043_regular.pdf. Accessed 04 September 2013

Gibbons DC (1986) The economic value of water. Resources for the Future Press, Washington DC 
Global Fire Power (2011) Global firepower nations by rank- strength in numbers. http://www.GlobalFirepower.com. Accessed 13 April 2012

Gohar AA, Ward FA (2010) Gains from expanded irrigation water trading in Egypt: an integrated basin approach. Ecol Econ 69:2535-2548

Güner SS (1999) Water alliances in the Euphrates-Tigris basin. In: Lonergran SC (ed) Environmental change, adaptation and security. Kluwer Academic Publisher, Dordrecht, pp 301-316

GWI (2010) Water tariff survey. Global Water Intelligence (GWI). http://www.globalwaterintel.com/tariff-survey/ Accessed 04 October 2013

Harou JJ, Pulido-Velazques M, Rosenberg DE, Medellín-Azuara J, Lund JR, Howitt RE (2009) Hydro-economic models: concepts, design, application, and future prospects. J Of Hydrol 375:627-643

Heerden JH, Blignaut J, Horridge M (2008) Integrated water and economic modeling of the impacts of water market instruments on South African economy. Ecol Econ 66:105-116

Hill CA (2000) The Garden of Eden: a modern landscape. Perspect On Sci And Christ Faith 52:31-46

Hole F, Zaitchik BF (2007): Policies, plans, practice, and prospects: irrigation in northeastern Syria. Land Degrad And Dev 18:133-152

INECO (2009) Institutional framework and decisionmaking practices for water management in Syria- towards the development of a strategy for water pollution prevention and control in the Barada river basin, Greater Damascus area. http://environ. chemeng.ntua.gr/ineco/ UserFiles/File/Deliverables/Publishable\%20Report\%20\%20Syria.pdf. Accessed 04 October 2013

Jobson S (2003) Water of strife: the geopolitics of water in the Euphrates-Tigris and Jordan river basin. The Royal Institute of International Affairs, Middle East Programme, Briefing Paper No. 4. http://www.chathamhouse.org/sites/default/files/ public/Research/Middle\%20East/ mep4waterofstrife.pdf Accessed 04 October 2013

Kavvas ML, Chen RZQ, Anderson ML, Ohara N, Yoon J (2011): A study of water balances over Tigris-Euphrates watershed. Phys And Chem Of The Earth 36:197-203

Kaya I (1998) The Euphrates-Tigris basin: an overview and opportunities for cooperation under international law. Arid Lands Newsletter, No. 44, Conflict Resolution and Transboundary Water Resources, Fall/Winter 1998. http://ag.arizona.edu/oals/ ALN/aln44/kaya.html. Accessed 04 October 2013

Keller AA, Sakthivadivel R, Seckler DW (2000) Water scarcity and the role of storage in development. International Water Management Institute (IWMI), Research Report 39, Colombo 
Kibaroglu A, Scheumann W (2013) Evolution of transboundary politics in the EuphratesTigris river system: new perspectives and political challenges. Glob Gov: A Rev Of Multilater And Int Organ 19:279-305

Kibaroglu A, Scheumann W (2011) Euphrates-Tigris rivers system: political rapprochement and transboundary water cooperation. In: Kramer A, Kibaroglu A, Scheumann W (eds) Turkey's water policy: national frameworks and international cooperation. Springer, Berlin, Heidelberg, pp 277-300

Kibaroglu A (2008) The role of epistemic communities in offering new cooperation frameworks in the Euphrates-Tigris river system. J Of Int Aff 61:183-198

Kibaroglu A (2007) Water for sustainable development in the Euphrates-Tigris river basin. Middle East Technical University Department, Ankara. http://www.gap.metu.edu. tr/html/yayinlar/ waterforsustainableAKibaroglu.pdf Accessed 04 October 2013

Kibaroglu A, Klaphake A, Kramer A, Scheumann W, Carrius A (2005) Cooperation on Turkey's transboundary waters. Status report commissioned by the German Federal Ministry for Environment, Nature Conservation and Nuclear Safety. Project No: 903 19 226. Berlin, Germany.

Kibaroglu A, Ünver IHO (2000) An institutional framework for facilitating cooperation in the Euphrates-Tigris river basin. Int Negot 5:311-330

Kolars J (1994) Problems of international river management: the case of the Euphrates. In: Biswas AK (ed) International waters of the Middle East - from Euphrates-Tigris to Nile. Oxford University Press. London, pp 44-94

Kramer A, Kibaroglu A (2011) Turkey's position towards international water law. In: Kramer A, Kibaroglu A, Scheumann W (eds) Turkey's water policy: national frameworks and international cooperation. Springer, Berlin, Heidelberg, pp 215-228

Kucukmehmetoglu M (2012) An integrative case study approach between game theory and pareto frontier concepts for the transboundary water resources allocations. J Of Hydrol 450:308-319

Kucukmehmetoglu M, Guldmann JM (2010) Multi-objective programming for the allocation of transboundary water resources: the case of the Euphrates and Tigris. J Of Water Resour Plan And Manag-ASCE 136:95-105

Kucukmehmetoglu M, Sen Z, Özger M (2010) Coalition possibility of riparian countries via game theory and fuzzy logic models. Water Resour Res 46:W12528

Kucukmehmetoglu M (2009) A game theoretic approach to assess the impacts of major investments on transboundary water resources: the case of the Euphrates and Tigris. Water Resour Manag 23:3069-3099

Kucukmehmetoglu M, Guldmann JM (2004) International water resources allocation and conflicts: the case of the Euphrates and the Tigris. Environ And Plan A 36:783-801. 
Kurdish Human Rights Project (eds) (2002) Downstream impacts of Turkish dam construction on Syria and Iraq: joint report of fact-finding mission to Syria and Iraq. http://www.thecornerhouse.org.uk/sites/thecornerhouse.org.uk/files/IraqSyri.pdf. Accessed 01 September 2013

Leb C (2010) The Tigris-Euphrates joint technical committee - deadlocked. International Union for Conservation of Nature (IUCN). http://cmsdata.iucn.org/downloads/ tigris_euphrates.pdf. Accessed 01 September 2013

MacQuarrie P (2004) Water security in the Middle East: growing conflict over development in the Euphrates-Tigris basin. Master thesis, Trinity College, Dublin.

McKinney DC, Karimov AK, Cai X (1997) Report on model development: Aral Sea regional allocation model for the Amu Darya river. Technical Report, US Agency for International Development, Environmental Policy and Technology Project, Central Asia Regional EPT Office, Almaty, Kazakstan. http://www.ce.utexas.edu/prof/ mckinney/papers/aral/Rpt-on-Amudarya.pdf. Accessed 04 October 2013

MunlaHasan A (2007) Water use efficiency in Syrian agriculture. National Agricultural Policy Center (NAPC), Working Paper No. 26. http://www.napcsyr.net/dwnldfiles/working_papers/en/26_water_eff_am_en.pdf. Accessed 04 October 2013

Ozdogan M., Woodcock C.E., Salvucci G.D., Demir H. (2006) Changes in summer irrigated crop area and water use in Southeastern Turkey from 1993 to 2002: implications for current and future water resources. Water Resour Manag 20: 467-488.

Öztan M, Axelrod M (2011) Sustainable transboundary groundwater management under shifting political scenarios: the Ceylanpinar aquifer and Turkey-Syria relations. Water Intern 36:671-685

Rahi KA, Halihan T (2010) Changes in the salinity of the Euphrates river system in Iraq. Reg Environ Chang 10:27-35

Republic of Iraq (2006) Municipal water supplies: strategy for water and land resources in Iraq. General Directorate for Water Resources Management, Technical Report Series, TR 04.

Ruf U (2006) Das Südostanatolienprojekt (GAP). Arbeitskreis Wasser im BBU: Virtuelles Wasser. http://www.akwasser.de/download/file/fid/165. Accessed 01 September 2013

Sener S (2007) Transboundary rivers in Turkey and effective use of their water- case study: Euphrates and Tigris rivers. Canakkale Onsekiz Mart University, Turkey. http://www.inweb.gr/twm4/presentations/Day_1/Session_1_III/13_Sener.pdf, Accessed 19 September 2013

Shahin M (1989) Review and assessment of water resources in the Arab Region. Water Intern 14:206-219 
Siehlow M, Reif J, von Hirschhausen C (2013) Water resource management in the Orange Senqu river basin: regional incentives and cooperation.

State of Israel (ed) (2002) Water in Israel: consumption and production in 2001. State of Israel, Ministry of National Infrastructures, Water Commission, Demand Management Division. http://gwri-ic.technion.ac.il/pdf/wcom/demand.pdf.

Accessed 01 September 2013

Tigrek S, Kibaroglu A (2011) Strategic role of water resources for Turkey. In: Kramer A, Kibaroglu A, Scheumann W (eds) Turkey's water policy: national frameworks and international cooperation. Springer, Berlin, Heidelberg, pp 27-42

Tilmant A, Pinte D, Goor Q (2008) Assessing marginal water values in multipurpose multireservoir systems via stochastic programming. Water Resour Res 44:W12431

Tilmant A, Kelman R (2007) A stochastic approach to analyze trade-offs and risks associated with large-scale water resources systems. Water Resour Res 43: W06425

Tolba MK, Saab NW (2009) Arab environment: climate change- impact of climate change on Arab countries. Arab Forum for Environment and Development 2009. Beirut, Lebanon. http://www.sciencedev.net/Docs/arab_climate_report.pdf. Accessed 04 September 2013

UAE (2008) United Arab Emirates interact. Emirates News Agency, WAM. http://www.uaeinteract.com/docs/UAE_per_capita_water_consumption_ 550_litres_per_day_survey/30613.htm. Accessed 19 September 2013

Warner J (2012) The struggle over Turkey's Ilisu Dam: domestic and international security linkages. Intern Environ Agreem: Polit, Law And Econ 12:231-250

Warner J (2008) Contested hydrohegemony: hydraulic control and security in Turkey. Water Altern 1:271-288

Ward FA, Michelsen A (2002) The economic value of Water in agriculture: concepts and policy applications. Water Policy 4:423-446.

Watkins K (2006) Human development report 2006- beyond scarcity: power, poverty and the global water crisis. United Nations Development Programme (UNDP). Palgrave Macmillan, New York.

Williams PA (2011) Turkey's water diplomacy: a theoretical discussion. In: Kramer A, Kibaroglu A, Scheumann W (eds) Turkey's water policy: national frameworks and international cooperation. Springer, Berlin, Heidelberg, pp 197-214

World Bank (2013) World development indicators 2013. The World Bank, Washington $\mathrm{DC}$

World Gazetteer (2010) Population data arranged by country/cities- Turkey, Syria, Iraq. http://www.world-gazetteer.com. Accessed 30 October 2011 
Wu X, Whittington D (2006) Incentive compatibility and conflict resolution in international river basin: a case study of the Nile basin. Water Resour Res 42:W02417

Yenigun K, Aydogdu MH (2010) Evaluation of irrigation and drainage systems of (Southeastern Anatolia Project) GAP, the Turkey's largest integrated water resource development project. Sci Res And Essays 5:3237-3253

Zawahri NA (2006) Stabilising Iraq's water supply: what the Euphrates and Tigris rivers can learn from the Indus. Third World Q 27:1041-1058 


\section{Appendix}

Table 8: Notation of the WATER-Model

\begin{tabular}{|c|c|}
\hline Sets & Description \\
\hline $\begin{array}{l}a, b \\
g \\
i, j \\
r\end{array}$ & $\begin{array}{l}\text { periods (rainy, dry) } \\
\text { groups (industry, agriculture, households) } \\
\text { nodes (demand, transport, supply) } \\
\text { regions (Turkey, Syria, Iraq) }\end{array}$ \\
\hline \multicolumn{2}{|l|}{ Parameters } \\
\hline 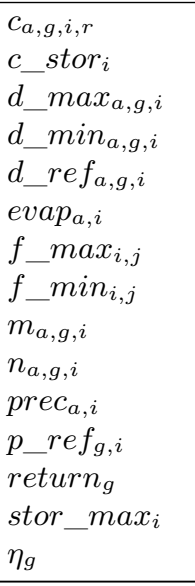 & $\begin{array}{l}\text { costs of consumption at node } \mathrm{i} \text { in region } \mathrm{r} \text { for group } \mathrm{g} \text { in period a } \\
\text { costs of storage at node } \mathrm{i} \\
\text { maximum demand at node } \mathrm{i} \text { for group } \mathrm{g} \text { in period a } \\
\text { minimum demand at node } \mathrm{i} \text { for group } \mathrm{g} \text { in period a } \\
\text { known reference demand at node } \mathrm{i} \text { for group g in period a } \\
\text { evaporation at node i in period a } \\
\text { maximum flow on arc }(\mathrm{i}, \mathrm{j}) \\
\text { minimum flow on arc }(\mathrm{i}, \mathrm{j}) \\
\text { slope of linear demand function at node i for group } \mathrm{g} \text { in period a } \\
\text { prohibitive price at node } \mathrm{i} \text { for group } \mathrm{g} \text { in period a } \\
\text { precipitation at node i in period a } \\
\text { known reference price at node i for group g } \\
\text { return flow factor for group } \mathrm{g} \\
\text { maximum storage capacity at node } \mathrm{i} \\
\text { price elasticity of demand for group } \mathrm{g}\end{array}$ \\
\hline \multicolumn{2}{|l|}{ Variables } \\
\hline $\begin{array}{l}d_{a, g, i, r} \\
d_{\text {_area }} a_{a, g, i, r} \\
\text { flow } \\
\text { stor_in } n_{a, i, r} \\
\text { stor_out } \\
z\end{array}$ & $\begin{array}{l}\text { demand at node } \mathrm{i} \text { in region } \mathrm{r} \text { for group } \mathrm{g} \text { in period a } \\
\text { area below demand function at node } \mathrm{i} \text { in region } \mathrm{r} \text { for group } \mathrm{g} \text { in period a } \\
\text { flow on arc }(\mathrm{i}, \mathrm{j}) \text { in period a } \\
\text { incoming storage controlled by region } \mathrm{r} \text { at node } \mathrm{i} \text { in period a } \\
\text { outgoing storage controlled by region } \mathrm{r} \text { at node } \mathrm{i} \text { in period a } \\
\text { welfare }\end{array}$ \\
\hline
\end{tabular}


Table 9: Seasonal tributary inflow at the transportation nodes [mcm/season]

\begin{tabular}{l|cc|c}
\hline \multirow{2}{*}{ Node } & \multicolumn{2}{|c|}{ Runoff } & Tributary \\
\cline { 2 - 3 } & rainy & dry & \\
\hline t1 & 15750 & 6750 & Turkish Tigris \\
t3 & 8050 & 3450 & Greater Zab \\
t4 & 3150 & 1350 & Diyala \\
t5 & 4200 & 1800 & Lesser Zab \\
t6 & 350 & 150 & Adhaim \\
t8 & 20160 & 8640 & Turkish Euphrates \\
t9 & 134 & 58 & Sajur \\
t10 & 246 & 106 & Belikh \\
t11 & 1859 & 797 & Khabur \\
t15 & 3500 & 1500 & Karkeh \\
\hline
\end{tabular}

Source: Own calculations based on Beaumont (1998), Erdem (2002), Kavvas, et AL. (2011), Kolars (1994), Sener (2007), and Shahin(1989). 


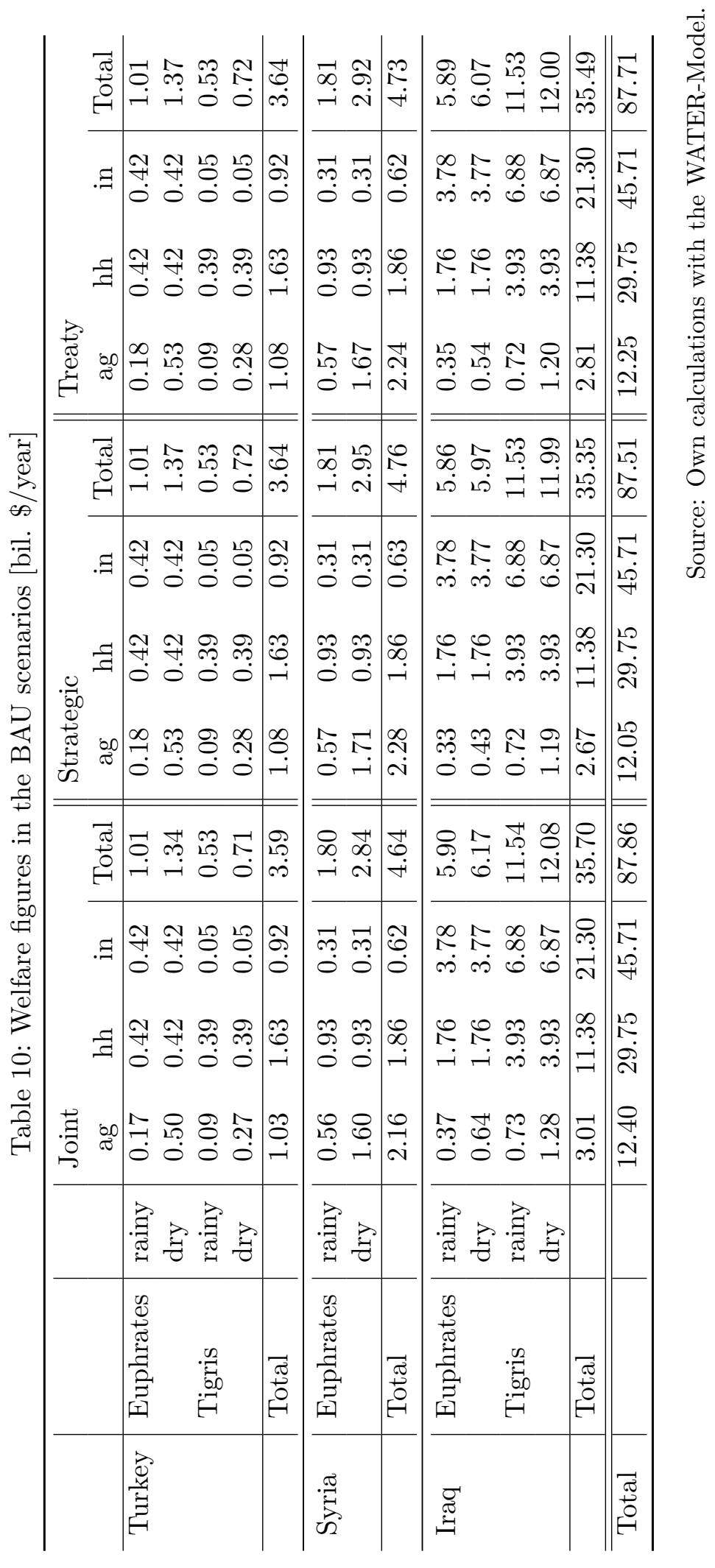




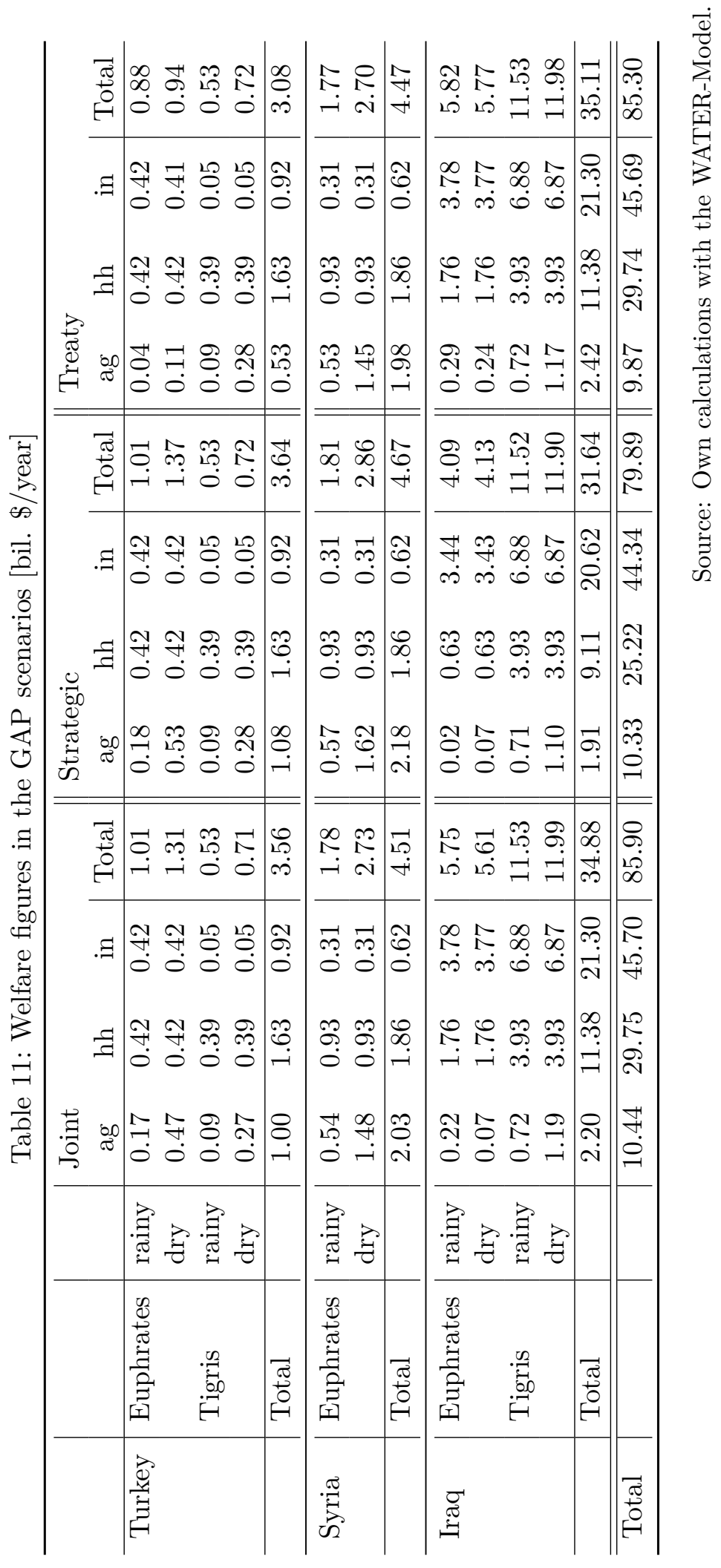




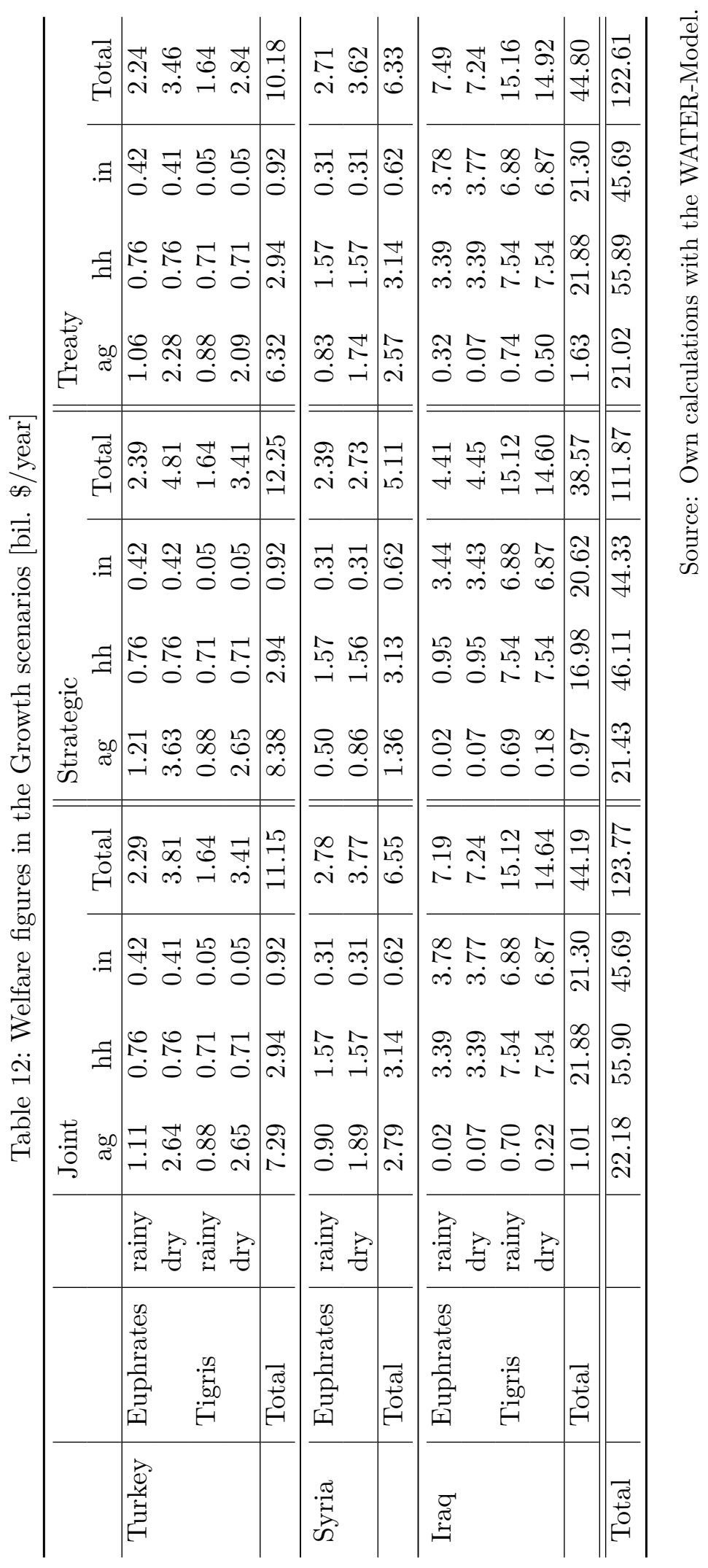




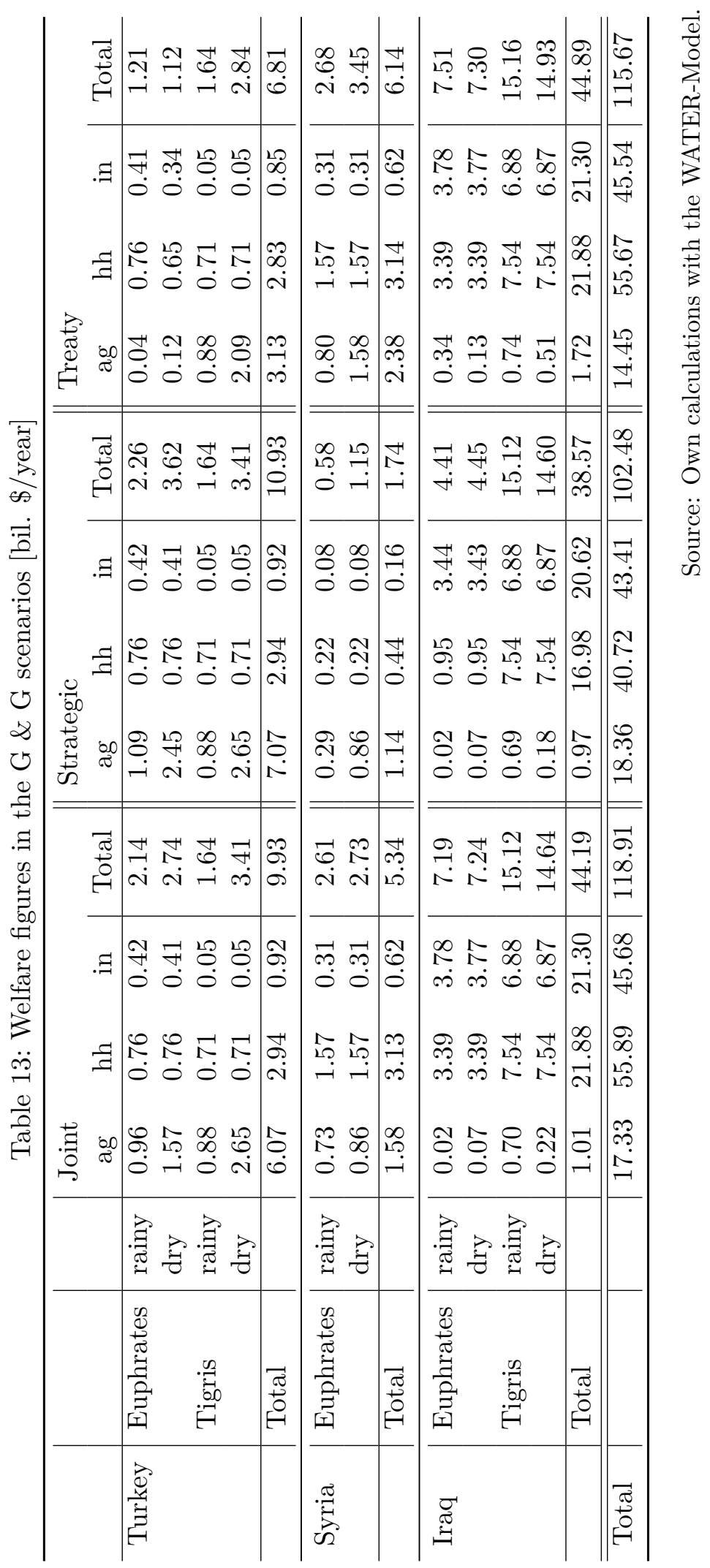

